\title{
Do Social Media Marketing Activities Improve Brand Loyalty? An Empirical Study on Luxury Fashion Brands
}

\author{
Abdulla H. Fetais ${ }^{1} \cdot$ Raed S. Algharabat ${ }^{1} \cdot$ Abdullah Aljafari $^{1} \cdot$ Nripendra P. Rana $^{1}$ (D)
}

Accepted: 19 February 2022 / Published online: 8 March 2022

(c) The Author(s) 2022

\begin{abstract}
This research aims to investigate the impact of social media marketing activities (SMMa) on brand loyalty directly and through mediating variables community engagement and lovemark. To propose a research model, we used the theories including lovemark theory, engagement theory and brand equity theory. As a result, this research investigates the impact of SMMa, community engagement, and lovemark on brand loyalty. Using an online survey, we collected data from 464 female participants who are following luxury fashion brands on major social networking sites including Facebook, Instagram, Snapchat, and Twitter. Results using PLS revealed that SMMa positively influences community engagement and lovemark. Moreover, we find positive relationships between community engagement, lovemark and brand loyalty. However, we find that SMMa has no direct influence on brand loyalty.
\end{abstract}

Keywords Social media $\cdot$ Community engagement $\cdot$ Lovemark $\cdot$ Brand loyalty $\cdot$ Fashion brands · Qatar

\section{Introduction}

Social networking sites (SNSs) provide challenges and opportunities to luxury fashion brands industry. Furthermore, SNS platforms have transformed the way in which luxury fashion brands interact with customers (Algharabat, 2017; Kim \& Ko, 2012; Mirkovski et al., 2019). Many of the luxury fashion brands have adapted different SNS platforms due to the benefits that such companies can gain (Kim \& Ko, 2010, 2012). Such benefits include interacting with current and potential consumers (Koivisto \& Mattila, 2018), increasing customer engagement (Alalwan et al., 2020; Liu et al., 2021), building stronger brand relationships (Alalwan et al., 2019; Algharabat, 2017; Dwivedi et al., 2021; Kelly et al., 2010),

Nripendra P. Rana

nrananp@gmail.com

Abdulla H. Fetais

afetais@qu.edu.qa

Raed S. Algharabat

ralgharabat@qu.edu.qa

Abdullah Aljafari

abdullah.aljafari@qu.edu.qa

1 Department of Management and Marketing, College of Business and Economics, Qatar University, P.O.

Box 2713, Doha, Qatar improving brand image and brand equity (Kim \& Ko, 2012), and eventually enhancing customer experience and positive responses (Arenas-Gaitan et al., 2013; Godey et al., 2016). In addition, Godey et al. (2013) assert that regardless of the purchase motivation a consumer might go for luxury fashion brands, the brand's mere presence on SNS influences customers' attitudes and perceptions in subtle ways because the brand remains the focal point. According to Godey et al. (2013), such positive influence may occur due to enhanced awareness and image perceptions, which in turn shape consumer preferences for linking consumers as such the brand often influences customers' attitudes and perceptions in different ways, including consumers' awareness of the brand, their image perceptions, and hence their preferences. Consumers' decision to buy luxury brands rely on three motivations, (i) their pleasure, (ii) symbol of achievement and success, or (iii) as a gift. Therefore, luxury fashion brands success rests on the balance between the three motivations (Kapferer, 2012).

Social media marketing activities (SMMa) is defined as the use of online social media applications and platforms to perform entertainment, customization, trendiness, purchase intentions, interaction and word of mouth (Kim \& Ko, 2012). Within luxury fashion brands on social media, we have noticed that extant literature on SMMa and engagement is still emerging (Dhaoui, 2014; Liu et al., 2021; Pentina et al., 2018) and that the number of studies 
which linked SMMa with lovemark are very limited. For instance, Nyadzayo et al. (2020) investigated the impact of brand image (unidimensional) on brand engagement in selfconcept (unidimensional), which influences brand loyalty without investigating the impact of lovemark. Algharabat (2017) linked SMMa with brand love (but not lovemark) for different brands (only $30 \%$ of the brands related to fashion) on Facebook. Moreover, extant literature on luxury fashion brands focuses on using a single social media platform such as Facebook (Algharabat, 2017), Twitter (Kar, 2021; Liu et al., 2021), WeChat (Liu et al., 2019). Godey et al. (2016) investigated the use of two SNSs namely, Facebook and Twitter. However, we contend that collecting data from customers on a specific SNS may not match consumer behavior in real life. Presumably, consumers have accounts on various SNSs and some of these are more preferable compared to others. Such preference may depend on the context (following a brand vs. following a celebrity). Thus, the current research allows consumers to pick the SNS preferred to follow luxury fashion brands.

Furthermore, extant literature that investigated the relationships between SMMa and engagement within luxury fashion brands did not focus on community engagement. Rather such literature focused on customer brand engagement. Therefore, a little is known about the linkage between SMMa and community members engagement. Investigating the direct linkages between SMMa and lovemark is still in its early stages and it needs more attention. For instance, previous research investigated the impact of SMMa on one dimension of the lovemark, brand love, but not brand respect (Algharabat, 2017). Thus, more research is needed to understand the nature of the relationship between SMMa and lovemark as a higher-order construct. Overall, we find that linking and empirically testing the relationships between SMMa, community engagement, lovemark and brand loyalty is important to build the nomological network. Furthermore, we noticed that studies investigating the linkages between lovemark and brand loyalty within SNSs for luxury fashion brands are also limited (Cho et al., 2018; Islam \& Rahman, 2016). We test our theoretical model in Qatar, which represents a unique context given its per capita income is one of the highest in the world. Based on the above discussion, this research aims to answer the following research questions:

RQ1. How does SMMa influence community engagement, brand loyalty and lovemark?

RQ2. How do community engagement and lovemark influence brand loyalty?

This study contributes to extant literature in several ways. First, our research model investigates SMMa, community engagement, lovemark, and brand loyalty in the context of luxury fashion brands. Extant literature focuses on some of the linkages of our proposed model in contexts other than luxuries. Second, this research is considered among the few that focuses on specific type of social media engagement, namely, community engagement (Algharabat \& Rana, 2020; Dessart, 2017). Third, we give respondents more freedom in choosing their preferred SNS for following their preferred luxury fashion brand, which captures consumer behaviour in a more realistic way. Finally, given that motivations and behaviours in terms of following fashion brands may differ across genders, we focus on one gender in this study: Qatari female consumers. This paper fits well under the broader remit of information systems research as SMMa are the outcome of social media applications and platforms, which are fundamentally the technological developments that provide both businesses and customers with high level of agility and up-to-date information. As SNSs are first a technological tool, this paper also provides various implications for information systems managers that are linked with the design and development of the social media pages of Facebook, Instagram, Snapchat and Twitter for the luxury fashion brands.

The structure for the rest of this research is as follows: First, we discuss extant literature review and the main theories behind our proposed research model. Then, we formulate our hypotheses. Second, we explain the main methods used to collect data. Third, we present the key results of this research. Finally, we elaborate on our results through discussion, implications for theory and practice and limitations followed by conclusion toward the end of the paper.

\section{Literature Review}

While we built our research model, we reviewed all the extant literature which has mentioned the linkage between any constructs of our proposed research model. We started the search by looking into the main constructs such as SMMa, community engagement, lovemark, and brand loyalty. As a result, we ended up with about 210 articles that have discussed these constructs. Then, we narrow down our search and try to find the articles that discussed our proposed constructs in social media platforms context and we focused our efforts on papers that linked the proposed constructs under the current study from both information systems (IS) and marketing perspectives and discussed luxury fashion brands over social media platforms. We find that the majority of the constructs from this study have been investigated mostly in the IS context such as SMMa (interaction, customisation, entertainment, trendiness and electronic word-ofmouth (eWOM)), or came as an application of IS in different social media platforms such as community engagement, and brand loyalty. 
However, we find that the notion of lovemark purely comes from marketing area and has not been discussed from an IS context. Hence, after this filtering, we find a limited number of studies that connected some of the investigated constructs in both the IS and marketing area. Thus, we believe that the extant marketing literature does not explicitly investigate the philosophy behind linking the IS constructs with the notion of lovemark, which could motivate users and thus increase their brand loyalty in the luxury fashion brands sector. Therefore, our attempt comes to identify the main constructs that would influence brand loyalty within the context of social media platforms for luxury fashion brands.

Therefore, we have built our research model based on previous studies, which investigated the context of luxury fashion brands SMMa within social media platforms. The reasons we decided to investigate the current constructs within fashion brand industry are related to the following:

1. Within the context of SNSs, the notion of lovemark has been investigated mainly by reflecting one dimension of this construct, namely, brand love but not brand respect. Therefore, we believe that the addition of lovemark as a multidimensional construct compresses of brand love and brand respect is important, particularly, within the context of fashion brands due to the importance of this construct to shape consumers' loyalty (Roberts, 2005).

2. We have added other constructs which have been tested within SNSs context such as SMMa, brand loyalty and engagement to test the validity of such connections within fashion brand industry. The following themes explain our main findings with the current published research:

\subsection{SMMa}

Previous studies (e.g., Alalwan et al., 2016; Godey et al., 2016; Kim \& Ko, 2012) assert the importance of using SMMa in different contexts. For instance, Kim and Ko (2012) conceptualise SMMa as a multidimensional construct, encompassing five sub-constructs, namely, interaction, customisation, entertainment, trendiness and electronic word-of-mouth (eWOM). However, some studies (e.g., Cheung et al., 2020a, b; Liu et al., 2021) assert that SMMa consist of four sub-dimensions including customisation, entertainment, trendiness and interaction, but not eWOM. Cheung et al. (2020a, b) justified this exclusion of eWOM from SMMa dimensions as a result of the ability of eWOM dimension to be measured via the notion of engagement rather than SMMa. The following sections explain the five sub-constructs of SMMa.

\subsubsection{Entertainment}

Within social media marketing context, entertainment related to the ability of social media platforms to create an enjoyable, fun, relaxation, escapism and playfulness experience which users can have over navigating a particular platform (Cheung et al., 2019; Manthiou et al., 2013). For instance, the usage of videos, photos, games and contests (Cheung et al., 2019) could be tools that often boost entertainment construct. Previous research asserts the importance of this activity over social media platform to enhance consumer-brand relationship, brand awareness, brand knowledge, brand image, brand equity and purchase intention (Algharabat, 2017; Barger et al., 2016; Kim \& Ko, 2012; Plume \& Slade, 2018; Seo \& Park, 2018). Thus, entertainment is a significant element, which drives users to adopt different social media platforms (Muntinga et al., 2011; Park et al., 2009).

\subsubsection{Customisation}

Godey et al. (2016) argue that customisation is a significant element within SMMa. The authors assert that customisation is related to the process of tailoring a particular service to satisfy users' preferences. Hence, marketers within different social media platforms have the technology to send customized messages to support their dialogue with consumers (France et al., 2016; Kim \& Ko, 2012; Zhu \& Chen, 2015). Furthermore, customization allows marketers to send personalised messages regarding different brands to increase customers' value in specific group within social media platforms to strengthen consumer-brand relationship (Zhu \& Chen, 2015). Accordingly, Godey et al. (2016) maintain that customization reflects the ability of social media platforms to offer customized service and information search. Thus, customization reflects individual preferences (Schmenner, 1986). For instance, post customization which takes a place via customized messages in social media platforms such Facebook posts (Zhu \& Chen, 2015) often targeting a particular target interested users.

\subsubsection{Interaction}

Social media platforms play a significant role in creating interaction which facilitates information sharing and enhances two-way communication (Dessart et al., 2015; Godey et al., 2016; Obeidat et al., 2020) via permitting users to exchange and share their ideas regarding different brands or products (Kim \& Ko, 2012). Thus, interaction aids customers to build proper knowledge regarding different brands and, hence, it fosters customers understanding 
via their interaction with the brand (Cheung et al., 2020a; Seo \& Park, 2018). Furthermore, consumers' interaction within social media enhance their discussion (Daugherty et al., 2008) of different products and brands (Aswani et al., 2018). Zhu and Chen (2015) categorise two main types of interaction within social media platforms i.e. (i) profilebased activities, and (ii) content-based activities. While profile-based activities focus on members' topics and discussions on social media platforms such as Twitter, WhatsApp, Facebook and others. Content-based activities focus on individual members' comments, discussions and contents on social media such as YouTube, Instagram, Flickr, and others that consumers like. Godey et al. (2016) clarify that the interaction element of the SMMa often enhances customers' discussion of brand usage and the latest news of brands.

\subsubsection{Trendiness}

Trendiness in social media reflects the ability of a particular brand within a particular social platform to deliver/ disseminate the latest and trendy information regarding a brand (Muntinga et al., 2011; Naaman et al., 2011) including novel ideas about brands (Gallaugher \& Ransbotham, 2010). Trendiness has been linked with consumers' awareness (Godey et al., 2016), brand love (Algharabat, 2017) and brand loyalty (Godey et al., 2016). Arrigo (2018) asserts the significant role of trendiness in SMMa. Liu et al. (2021) emphasized on analysing trendiness as a major component of SMMa that attracted many users to follow luxury brands over social media context. Khan et al. (2019) define trendiness, within apparel industry, based on latest information and trendiness information.

\subsection{5 eWOM}

Previous studies (Algharabat, 2017; Godey et al., 2016) assert the significant role of eWOM as a tool that enhance social media users to interact and communicate by different customers (actual, potential or former) about different brands to deliver their opinions or experiences (HennigThurau et al., 2015). Thus, eWOM is considered by different users as credible and trustworthy source of information (Algharabat, 2017; Cheung et al., 2019; Nam et al., 2020). This fact is supported by the evidence that users are trusting users like themselves more than they trust a company on social media platforms (Algharabat \& Rana, 2020; Sijoria et al., 2018). Therefore, eWOM is a helpful tool to enhance and strengthen consumer-brand relationships (Kudeshia \& Kumar, 2017). Moreover, eWOM plays a vital role in building consumers' attitudinal brand loyalty (Godey et al., 2016).

\subsection{Lovemark}

The following sections explain more about the dimensions of lovemark brand, namely, brand love and brand respect.

\subsubsection{Brand Love}

Previous research (Albert et al., 2008; Algharabat, 2017; Carroll \& Ahuvia, 2006) defined brand love based on emotional attachment and affection, which consumers have for a particular brand (Albert et al., 2008; Carroll \& Ahuvia, 2006). Therefore, this brand-consumer relationship is rooted on the interpersonal theory of love and triangular theory of love (Fournier, 1998; Sternberg, 1986, 1997). Furthermore, consumers' deep emotions reflect their beliefs in a brand which in turn is linked with consumers' evaluations of the brand (Carroll \& Ahuvia, 2006; Cross et al., 2000). Moreover, brand love reflects the relationship between a consumer self-image and the brand image (Albert et al., 2008; Algharabat, 2017; Batra et al., 2012). Further, brand love is also mirroring consumers' positive experience with a brand and their aspiration to consume the brand (Albert et al., 2008). Previous research (Algharabat, 2017; Vernuccio et al., 2015) maintains that the notion of brand love, within social media context, is still under investigation and hence more research should examine the significance of this notion and measure the impact of SMMa on the creation of brand-consumer relationship.

For instance, Algharabat (2017) posits that brand love is measured via liking the brand, yearning the brand and being committed to the brand. Furthermore, previous research (Algharabat, 2017; Batra et al., 2012; Thomson et al., 2005) asserts that the "heart-shaped icon" and the "like button" reflect brand love and hence signify affirmative emotional signs for consumer-brand relationships. Algharabat (2017) asserts that nascent research on brand love identified emotions, attachment, passionate, positive evaluation, declaration, and evaluations as indicators to brand love which often enhance consumer-brand relationship (Albert et al., 2008; Carroll \& Ahuvia, 2006). Thus, the existing literature on brand love shows its significant role on different decisions to improve customer-brand relationship such as customers' attitudes and emotions toward the brand, accepting a particular brand, build brand loyalty, spread eWOM, enhancing consumers' actual purchase and purchase intention, and reducing price sensitivity (Ahuvia, 2005; Albert et al., 2008; Algharabat, 2017; Batra et al., 2012; Carroll \& Ahuvia, 2006; Wallace et al., 2014).

\subsubsection{Brand Respect}

Roberts (2005) maintains that brand respect reflects consumers' positive perceptions toward a specific brand. Such perception centred on consumers' evaluation of the brand 
performance, reputation, trust and performance. Thus, within social media platforms, consumers' discussion of a particular brand often builds on brand respect which is responsible about illustrating the brand's performance, which in turn enhances consumers' sense of trust, and builds brand reputation (Roberts, 2005). From psychological and sociological points of view, respect considered as an important indicator for shaping human interpersonal relationships (Zacchilli et al., 2009). For instance, Frei and Shaver (2002) assert that respect is related to consumers' attitudes and is determined by quality of their feelings and thoughts. Thus, online brand communities, in different social media platforms, often play a significant role in creating remarkable and significant experiences with a particular brand via sending relevant messages by customers to other customers to enhance brand respect. Such messages express customers' perceptions about a particular brand performance and hence build brand respect (Giovanis \& Athanasopoulou, 2018).

\subsection{Brand Loyalty}

Liu et al. (2012) assert that brand loyalty reflects customer's attachment towards a particular brand. Furthermore, the authors posit that brand loyalty mirrors different dimensions such as cognitive, emotional, and behavioural attachments. Hence, extant literature classified brand loyalty into two main dimensions; attitudinal loyalty and behavioural loyalty (Yoo \& Donthu, 2001). While attitudinal loyalty measured via consumers' feelings and purchase intention of the brand (Liu et al., 2012), behavioural loyalty measured via actual buying of the brand (Leckie et al., 2016). Thus, extant literature within social media marketing considered brand loyalty as an important outcome (Algharabat, 2017; Dwivedi, 2015; Dwivedi et al., 2021; Wallace et al., 2017) for brands and firms.

\subsection{Community Engagement}

Customer engagement has derived the attention of many marketing scholars, in particular within the social media platforms (Alalwan et al., 2019; Algharabat, 2018; Algharabat et al., 2018, 2020; Algharabat \& Rana, 2020; Dessart, 2017; Dessart et al., 2016; Preuveneers et al., 2020; Trivedi et al., 2018) and there are growing research on conceptualizing and modelling this notion (Hollebeek et al., 2016). Customer engagement could be classified into two different types; customer brand engagement (Hollebeek et al., 2016; Tsai \& Men, 2017) and social media engagement (Algharabat \& Rana, 2020; Dessart, 2017), which consist of community engagement and brand engagement. To that end, we noticed the lack of empirical studies (Algharabat \& Rana,
2020; Dessart, 2017), which centred on investigating community engagement.

Therefore, previous studies define community engagement based on consumer interaction with other consumers in a specific social media community and consider it as one type of social media engagement. Previous research on this area agrees that community engagement is a multidimensional construct consists of affective, cognitive and behavioural aspects (Algharabat, 2018; Algharabat et al., 2018, 2020; Calder et al., 2009; Dessart, 2017; Dessart et al., 2016; Hollebeek et al., 2014; Hollebeek, 2011a, b). Furthermore, Brodie et al. (2013) emphasise that social media engagement is context-specific within a particular community such as social media platforms (Geissinger \& Laurell, 2016). Based on the fact that social media platforms (Facebook, YouTube, Instagram, blogs and Flickr) allow users to participate in exchanging and creating a particular context (Kaplan \& Haenlein, 2010), it facilitates consumers' interaction with other consumers via community engagement (Brodie et al., 2013; Zaglia, 2013).

\section{Theoretical Background, Conceptual Model and Hypotheses Development}

We have used service-dominant (S-D) logic theory (Lusch \& Vargo, 2010; Vargo \& Lusch, 2008), lovemark theory (Roberts, 2005) and brand equity theory (Keller, 1993) to propose research model. We provided the main justifications of adopting the mentioned theory while we described them below. Moreover, we adopted the notion of SMMa (Godey et al., 2016; Kim \& Ko, 2012) because such activities often help users to be engaged with a particular brand and hence this facilitates sharing important information, customize the service and have hedonic values. Accordingly, SMMa comprises of five sub-constructs namely, interaction, customisation, entertainment, eWOM and trendiness.

\subsection{Lovemark Theory}

Lovemark theory (Roberts, 2005) centred on marketing relationships. Roberts (2005) argues that lovemark dimensions consist of two aspects of the brand i.e., (i) functional aspect, which is reflected by the brand's performance, reputation and trust, (ii) and emotional aspect, which is mirrored by consumers emotional relationship with the brand. According to Roberts' (2005) lovemark theory, lovemark related to brands, experience and events that consumers' avidly love (Cho et al., 2015). Roberts (2005) asserts that lovemark for a particular brand should have the highest level of love and respect experienced by consumers in comparison to other terminologies such as brand, fads, and products. Therefore, 
lovemark brand centred on combining brand love and brand respect and it is an important tool to build and maintain consumer-brand relationships, which leads to loyalty (Pawle \& Cooper, 2006). Therefore, we have adopted lovemark theory due to the theory ability to explain brand love and brand respect. Within the context of the current study of females' luxury fashion brands, we believe that the dimensions of lovemark are significant and should be included.

\subsection{S-D logic Theory}

Engagement as construct has been derived from the S-D logic theory, which centred on marketing relationships. Accordingly, S-D logic theory is based on the fact that consumers with a high level of relationship with a brand/product are characterized as being interactive with other consumers and have co-creative experience with the firm and the brand (Vargo \& Lusch, 2008). As a result, previous research (Brodie et al., 2013; Lusch \& Vargo, 2010) posits that engagement as a construct is enhanced by customer's co-creative and interactive experiences. Therefore, we relied on the S-D logic theory to explain community engagement that centred on affective, cognitive and behavioural dimensions. Furthermore, community engagement reflects the ability of the community members to interact with other members and to reflect the main co-creation values, which members can get from such online communities (Brodie et al., 2013; Dessart, 2017). Furthermore, as S-D logic theory based on interaction and co-creation constructs, it is more suitable for IS context (Chatterjee et al., 2021).

\subsection{Brand Equity Theory}

The notion of brand equity has significantly developed major changes in the brand field. Particularly, Keller's (1993) model of brand equity considered a valid example on measuring brand equity. The model comprises of two dimensions, namely, brand awareness and brand image. Brand awareness is linked with customers' ability to recall or recognise a brand and hence brand awareness will enhance consumers to identify a particular brand under different situations (Keller, 1993; Rossiter \& Percy, 1987). Therefore, brand awareness is related to the likelihood that customers will easily remember and recognize a brand (Keller, 1993). On the other hand, Keller (1993) articulates that brand image reflects the brand associations in customers' mind. At the current study, we decided to examine the influence of brand loyalty not any other dimensions of brand equity. This decision comes as result of Algharabat et al.'s (2020) study which finds that within social media context and when linking engagement with brand equity elements only brand loyalty works.

Further, within the context of social media the majority of studies focused on investigating brand loyalty in comparison to other components in brand equity (Dessart, 2017; Hollebeek et al., 2014; Leckie et al., 2016; Plume \& Slade, 2018). Therefore, we decided to adopt brand equity theory to examine the role of brand loyalty. We believe that brand loyalty provides the ability to explain customers' attitude and purchase reasons. Thus, the majority of IS studies have adopted brand loyalty due to its significant role in measuring users' intentions and behaviour towards social media (Algharabat et al., 2020; Dwivedi, 2015; Hollebeek et al., 2014; Laroche et al., 2013; Leckie et al., 2016; Nyadzayo et al., 2020; Vivek et al., 2012). Deriving from the above discussion and considering the justification for building on the theoretical underpinning of the above three theories, we propose a research model in Fig. 1 below:

\subsection{Hypotheses Development}

Figure 1 shows this research model. Moreover, some of the proposed hypotheses were built based on existing literature $\left(\mathrm{H} 1_{\mathrm{b}}\right.$ and $\left.\mathrm{H} 3\right)$. However, the other hypotheses have not been tested within SNSs for luxury fashion brands $\left(\mathrm{H}_{\mathrm{a}}, \mathrm{H} 1_{\mathrm{c}}\right.$ and H2). Therefore, our proposed research model investigated some of relationships among constructs that have not been tested within the context of SMMa luxury fashion brands and to the best of our knowledge, we are hypothesising these linkages for the very first time through this research using Fig. 1.
Fig. 1 Proposed Research Model ( Adapted from Algharabat \& Rana, 2020; Dessart, 2017; Godey et al., 2016; Kim \& Ko, 2012; Roberts, 2005; Walsh et al., 2009; Yoo \& Donthu, 2001)

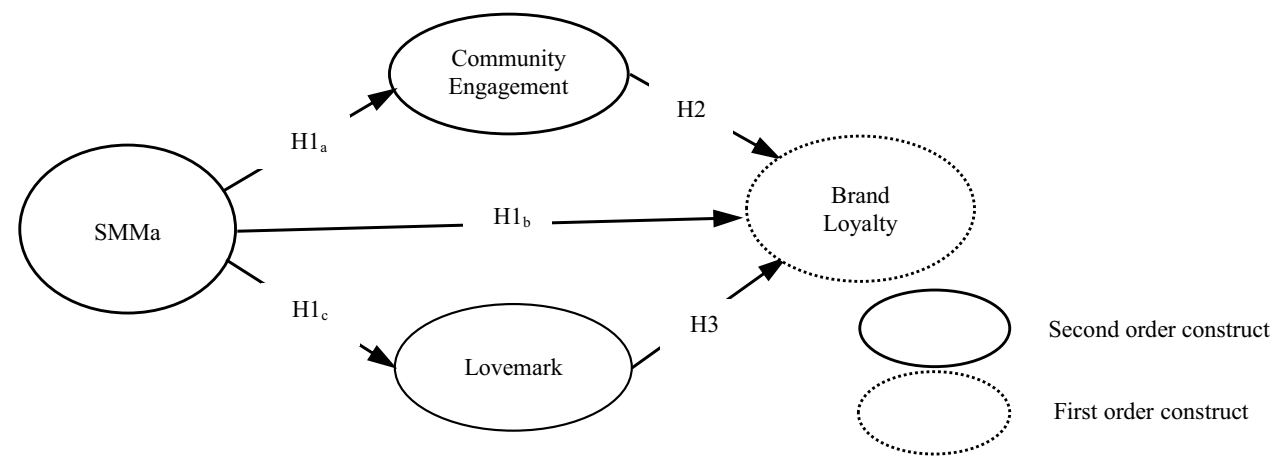




\subsubsection{SMMa and Community Engagement}

Community engagement reflects consumer-brand relationship (Hollebeek et al., 2014). Thus, this notion defined as a psychological position, which reflects consumers' desire for a particular brand. Extant literature asserts the positive relationships between SMMa and engagement. For example, Schultz and Peltier (2013) articulate the ability of social media platforms to enhance consumer-brand interaction, and hence to increase consumer brand engagement. At the same context, Barger et al. (2016) posit the significant association between the content that social media, which provides to consumers via their posts and their engagement with the brand community. Swani et al. (2013) explained the positive associations between consumers' affective posts, on social media platforms, which reflects their feelings and their engagement. De Vries et al. (2012) assert that consumers' brand posts influence consumer brand engagement and thus community engagement. Simon and Tossan (2018) argued that consumers' sharing values via social media platforms often strengthening their engagement with the brand and hence, increase their community belongingness. Therefore, previous research on engagement explains the importance of consumers' interactive experience in building consumerbrand relationship (Algharabat \& Rana, 2020; Bento et al., 2018; Habibi et al., 2014; Hollebeek, 2011a). Furthermore, previous literature shows that such an experience often builds by relying on different elements of social media marketing (Algharabat, 2017; Barger et al., 2016; Cheung et al., 2020a, b; De Vries \& Carlson, 2014; Simon \& Tossan, 2018).

During the last years, extant literature empirically asserts the positive relationships between SMMa and consumer engagement with its different types. For instance, Cheung et al. (2020a, b) found a positive relationship between SMMa (i.e., interaction, eWOM, and trendiness) and consumer brand engagement. The entertainment element of SMMa often enhance consumers' affection part (Agichtein et al., 2008; Ashley \& Tuten, 2015; Hollebeek et al., 2014; Ismail, 2017; Merrilees, 2016). Furthermore, SMMa often provides consumers with the needed information which often answers their concerns (Rohm et al., 2013). Such information can be customized as per customers' needs such as product attributes, features and prices. SMMa are likely to influence both consumers' cognitive and affective parts of the engagement and to improve consumers' understanding of the brand (Phan et al., 2011) and hence could help achieve the activation part of the engagement (Dessart et al., 2015; Merrilees, 2016).

Interactive brand pages over social media platforms inspire consumers-brand communication, and hence improve consumers' perceptions of the brand (Ismail, 2017). According to Manthiou et al. (2014), active sharing of information via posts, comments, liking, and following among consumers can strengthen their engagement with the social media community (Dessart et al., 2015; Hanna et al., 2011). Thus, the interactivity element of social media enhance consumers' affective, cognitive and behavioural aspects of the engagement (De Vries et al., 2012; Leckie et al., 2016; Manthiou et al., 2014; Vivek et al., 2012). For instance, the ability, of different platforms within social-media context (i.e., Instagram, Facebook and Twitter), to permit consumers to discuss their ideas, like, retweet, share and chat with others regarding brands often strengthening consumers engagement (Schivinski \& Dabrowski, 2015; Vivek et al., 2012). Interaction also takes place when consumers share their ideas, evaluation, and feedback (Hidayanti et al., 2018; Hoyer et al., 2010). Such interaction often ends up with particular actions such as actual purchase or purchase intention (Chen et al., 2011; Laroche et al., 2013).

Brand trendiness helps building consumers' perceptions of the brand as a leading one. Furthermore, brand trendiness motivates users to search the up-to-date information on social media brand page. For instance, brand trendiness is reflected via consumers' discussion on a particular brand over social media platforms. Thus, when a company posts the latest information about a particular brand, this will attract consumers' attention and thus it may post their feelings, thinking and actions. In turn, this often enhances consumers' affective, cognitive, and behavioural elements of their engagement (Chan et al., 2014; Dessart et al., 2015; Gallaugher \& Ransbotham, 2010; Liu et al., 2021). Within luxury fashion brand context, Nyadzayo et al. (2020) assert the positive relationship between SMMa and brand engagement in self-concept. Based on the above discussion, the following hypothesis can be formulated:

$\mathrm{H} 1_{\mathrm{a}}$ : SMMa attributed to females' luxury fashion brands in SNSs will have a positive influence on community engagement.

\subsubsection{SMMa and Brand Loyalty}

Previous research posits the significant relationship between SMMa and brand equity. For instance, extant literature (Bruhn et al., 2012; Kim \& Ko, 2012) articulates the positive association between SMMa and brand equity. Mangold and Faulds (2009) assert that SMMa represent a form of online communication mix, which combines employees to enhance brand communication. Bruhn et al. (2012) maintain that different tools of SMMa have a positive influence on brand equity. The authors assert that SMMa have a significant influence on both brand image and brand awareness. Godey et al. (2016) find a positive influence of SMMa on brand equity (measured as a second order with brand awareness and brand image). Yazdanparast et al. (2016) assert the significant relationship between SMMa and brand 
awareness. Godey et al. (2016) reported the significant relationship between SMMa (in particular the entertainment element) and brand equity (in particular the dimension of brand awareness). Ismail (2017) finds a positive impact of SMMa on brand loyalty. Ibrahim (2021) conducted a meta-analysis study to investigate the relationship between SMMa and brand loyalty and reported the positive relationship between SMMa and brand loyalty. Based on the above discussion, the following hypothesis can be formulated:

$\mathrm{H} 1_{\mathrm{b}}$ : SMMa attributed to females' luxury fashion brands in SNSs will have a positive influence on brand loyalty.

\subsubsection{SMMa and Brand Lovemark}

Roberts (2005) asserts that lovemark consists of two dimensions: brand love (positive affect) and brand respect (positive cognition) (Pawle \& Cooper, 2006). Therefore, brand lovemark is a brand with high levels of both love and respect (Roberts, 2005). Within offline context, Shimp and Madden (1988) assert that the notion of brand respect comes because of consumers' perceptions of high quality and value of a particular brand. Furthermore, the authors posit the significant role of customers' positive feelings as a main deriver for brand respect. Thus, the relationship between SMMa and brand lovemark has been investigated in the literature. However, the very limited research has investigated this relationship, taking into considerations that lovemark consists of two dimensions, brand love and brand respect. Extant research disused this relationship but not in a clear way.

For instance, Algharabat (2017) reported the significant relationship between SMMa and brand love. Other studies such as Okazaki et al. (2009) investigated the ability of SMMa to enhance engagement. Wallace et al. $(2014,2017)$ reported the impact of self-expressive brands on brand love using Facebook context. Huber et al. (2015) find a positive relationship between utilitarian, hedonic values and brand love. Therefore, to the best of the authors' knowledge, we believe that previous research within online communities, except for Algharabat (2017), did not link the relationship between SMMa and brand love. Vernuccio et al. (2015) investigate the relationship between engagement (measured via some SMMa) and brand love. Giovanis and Athanasopoulou (2018) emphasise the significant relationship between SMMa (eWOM) and brand lovemark. Similarly, the relationship between SMMa and brand respect is still under investigation and we consider this relationship as unrevealed due to lack of research which links the two constructs. Based on the above discussion, the following hypothesis can be formulated:

$\mathrm{H} 1_{\mathrm{c}}$ : SMMa attributed to females' luxury fashion brands in SNSs will have a positive impact on lovemark.

\subsubsection{Community Engagement and Brand Loyalty}

The linkage between engagement and brand loyalty is rooted within social media context. For example, previous literature (Bruhn et al., 2012; Hutter et al., 2013; Mishra et al., 2014; Schivinski \& Dabrowski, 2015; Shareef et al., 2019) articulates the significant relationship between SMMa and customer based brand equity. Furthermore, Bruhn et al. (2012) and Hutter et al. (2013) reported the significant relationship between engagement dimensions (affect and affection) and brand awareness. Dwivedi (2015) articulates the positive relationship between engagement (affection, cognitive processing and activation) and brand loyalty. Similarly, previous research (e.g., Algharabat et al., 2020; Hollebeek et al., 2014; Hollebeek, 2011a; Leckie et al., 2016; Vivek et al., 2012) reported the positive relationship between engagement dimensions (consumers' cognitive processing, affective part) and brand loyalty. Within luxury fashion brand context, Nyadzayo et al. (2020) assert the positive relationship between brand engagement in self-concept and brand loyalty. Based on the above discussion, the following hypothesis can be formulated:

$\mathrm{H} 2$ : There is a positive relationship between female community engagement and brand loyalty in SNSs luxury fashion brand pages.

\subsubsection{Lovemark and Brand Loyalty}

According to lovemark theory (Roberts, 2005), lovemark is measured via two dimensions brand love and brand respect. Roberts (2005) asserts that lovemark helps improving consumer-brand relationships. The author posits the positive correlation between lovemark brand and brand loyalty. Giovanis and Athanasopoulou (2018) posit the significant relationship between lovemark and brand loyalty (attitudinal loyalty). Further evidence regarding the significant association between lovemark and brand loyalty can be found in recent literature. For instance, Veloutsou and Aimpitaksa (2017) stated the significant relationship between lovemark with its two dimensions and brand loyalty. Moreover, the authors posit that lovemark is one of the main factors, which convince consumers to accept higher prices of the brand in comparison to competitor prices and hence it encourages them to positively spread positive word of mouth. Chen et al. (2020) postulate the significant relationship between lovemark and brand loyalty. Furthermore, extant literature (Cho et al., 2015, 2018; Pawle \& Cooper, 2006) asserts the direct impact of lovemark on brand loyalty. Other scholars (Algharabat, 2017; Carroll \& Ahuvia, 2006) examined the influence of one dimension of lovemark (brand love) on brand loyalty. For instance, Algharabat (2017) and Carroll and Ahuvia (2006) found a 
Table 1 Summary of measurement scales

\begin{tabular}{|c|c|c|c|c|c|c|c|}
\hline Measurement Scale & FL & $\mathrm{CR}$ & AVE & Measurement Scale & FL & $\mathrm{CR}$ & AVE \\
\hline Customization & & 0.830 & 0.710 & Affective Engagement & & 0.893 & 0.626 \\
\hline CUST1 & 0.840 & & & AEG2 & 0.739 & & \\
\hline CUST2 & 0.845 & & & AEG3 & 0.723 & & \\
\hline Trendiness & & 0.709 & 0.550 & AEG4 & 0.852 & & \\
\hline TRE1 & 0.730 & & & AEG5 & 0.810 & & \\
\hline TRE2 & 0.753 & & & AEG6 & 0.824 & & \\
\hline Interaction & & 0.785 & 0.549 & Cognitive Engagement & & 0.917 & 0.649 \\
\hline INT1 & 0.771 & & & CEG1 & 0.780 & & \\
\hline INT2 & 0.703 & & & CEG2 & 0.796 & & \\
\hline INT3 & 0.749 & & & CEG3 & 0.812 & & \\
\hline Entertainment & & 0.761 & 0.614 & CEG4 & 0.793 & & \\
\hline ENT1 & 0.790 & & & CEG5 & 0.849 & & \\
\hline ENT2 & 0.777 & & & CEG6 & 0.803 & & \\
\hline Brand Love & & 0.880 & 0.596 & Behavioral Engagement & & 0.917 & 0.581 \\
\hline BLO1 & 0.719 & & & BEG1 & 0.740 & & \\
\hline BLO2 & 0.791 & & & BEG2 & 0.749 & & \\
\hline $\mathrm{BLO} 3$ & 0.778 & & & BEG3 & 0.782 & & \\
\hline BLO4 & 0.793 & & & BEG4 & 0.729 & & \\
\hline BLO5 & 0.776 & & & BEG6 & 0.771 & & \\
\hline Brand Respect & & 0.744 & 0.502 & BEG7 & 0.784 & & \\
\hline BR1 & 0.695 & & & BEG8 & 0.764 & & \\
\hline $\mathrm{BR} 2$ & 0.960 & & & BEG9 & 0.777 & & \\
\hline \multirow[t]{4}{*}{ BR3 } & 0.719 & & & Brand Loyalty & & 0.794 & 0.562 \\
\hline & & & & BL1 & 0.790 & & \\
\hline & & & & BL2 & 0.733 & & \\
\hline & & & & BL3 & 0.726 & & \\
\hline
\end{tabular}

FL Factor loading, CR Composite Reliability, AVE Average Variance Extracted significant influence between brand love on brand loyalty. Based on the above discussion, the following hypothesis can be formulated:

H3: Lovemark positively influences females brand loyalty toward luxury fashion brands in SNSs (Tables 1, 2, 3, 4 and 5).

\section{Research Methodology}

In order to test hypotheses, we collected data using an online survey targeting Qatari female consumers. At the beginning of the survey, respondents were requested to identify their preferred social media platform to follow fashion brands from a list (e.g., Facebook, Instagram, Snapchat, Twitter,

Table 2 Discriminant validity

\begin{tabular}{lllllllllllll}
\hline & CR & AVE & AEG & BL & BEG & BLO & BR & CEG & CUST & ENT & INT & TRE \\
\hline AEG & 0.893 & 0.626 & $\mathbf{0 . 7 9 0}$ & & & & & & & & & \\
BL & 0.794 & 0.562 & 0.675 & $\mathbf{0 . 7 5 0}$ & & & & & & & & \\
BEG & 0.917 & 0.581 & 0.758 & 0.658 & $\mathbf{0 . 7 6 0}$ & & & & & & & \\
BLO & 0.88 & 0.596 & 0.713 & 0.597 & 0.454 & $\mathbf{0 . 7 7 0}$ & & & & & & \\
BR & 0.744 & 0.492 & 0.628 & 0.672 & 0.55 & 0.654 & $\mathbf{0 . 7 0 0}$ & & & & & \\
CEG & 0.917 & 0.649 & 0.652 & 0.546 & 0.807 & 0.458 & 0.545 & $\mathbf{0 . 8 1 0}$ & & & & \\
CUST & 0.830 & 0.710 & 0.423 & 0.416 & 0.318 & 0.582 & 0.548 & 0.238 & $\mathbf{0 . 8 4 0}$ & & & \\
ENT & 0.761 & 0.614 & 0.516 & 0.434 & 0.306 & 0.719 & 0.63 & 0.244 & 0.602 & $\mathbf{0 . 7 8 0}$ & & \\
INT & 0.785 & 0.549 & 0.460 & 0.368 & 0.384 & 0.529 & 0.589 & 0.300 & 0.579 & 0.632 & $\mathbf{0 . 7 4 0}$ & \\
TRE & 0.709 & 0.55 & 0.356 & 0.336 & 0.156 & 0.578 & 0.566 & 0.096 & 0.621 & 0.634 & 0.639 & $\mathbf{0 . 7 4 0}$ \\
\hline
\end{tabular}

Square root of AVEs is across diagonal in Bold 
Table 3 Hetrotrait - Monotrait ratio

\begin{tabular}{|c|c|c|c|c|c|c|c|c|c|c|}
\hline Construct & 1 & 2 & 3 & 4 & 5 & 6 & 7 & 8 & 9 & 10 \\
\hline \multicolumn{11}{|l|}{ 1. BL } \\
\hline 2. BEG & 0.601 & & & & & & & & & \\
\hline 3. BLO & 0.599 & 0.452 & & & & & & & & \\
\hline 4. $\mathrm{BR}$ & 0.512 & 0.549 & 0.645 & & & & & & & \\
\hline 5. CEG & 0.542 & 0.452 & 0.453 & 0.544 & & & & & & \\
\hline 6. AEG & 0.479 & 0.423 & 0.569 & 0.648 & 0.561 & & & & & \\
\hline 7. CUST & 0.417 & 0.318 & 0.584 & 0.548 & 0.236 & 0.348 & & & & \\
\hline 8. ENT & 0.437 & 0.306 & 0.523 & 0.573 & 0.242 & 0.372 & 0.601 & & & \\
\hline 9. INT & 0.367 & 0.386 & 0.531 & 0.589 & 0.298 & 0.411 & 0.576 & 0.531 & & \\
\hline 10. TRE & 0.339 & 0.156 & 0.581 & 0.564 & 0.102 & 0.210 & 0.467 & 0.632 & 0.536 & \\
\hline
\end{tabular}

and others) along with their preferred fashion brand. Mainly we followed previous research in this area (Gautam \& Sharma, 2017; Godey et al., 2016; Kim \& Ko, 2012; Liu et al., 2019, 2021) and we selected the following luxury fashion brands (Burberry, Hermès, Louis Vuitton, Dior, and Gucci, Chanel, Marc Jacobs, Dolce and Gabbana, Saint Laurent, Versace, Michael Kors, Armani, Christian Louboutin, Ralph Lauren, Valentino, Alexander McQueen and Prada). The survey instructed respondents to keep the preferred social media platform and the preferred fashion brand in mind as they respond to questions. At the top of each set of questions respondents were reminded that they need to take the social media platform and the fashion brand they chose at the beginning of the survey in consideration as they respond to the questions. To foreshadow our results, Instagram is the most preferable social media platform to follow fashion brands and Chanel is the most preferable fashion brand to be followed (Table 6).

\subsection{Sample and Data Collection}

We collected the data from Qatari females in the state of Qatar. Students at a major governmental university in Qatar were recruited to collect data utilizing an online survey. Specifically, students shared the link of the survey with female friends (with a minimum age of 18 years) and relatives who follow fashion brands on social media in return for partial course credit. We opted for a convenience sampling approach because it is difficult to obtain adequate response through probabilistic sampling in Qatar (Hair et al., 2014). Table 7 provides more information about our sample demographics.

Table 8 shows the frequency of preferred luxury fashion brands. Moreover, Table 9 shows the number of preferred luxury fashion brand followers until November 2021. A total of 705 responses were received. However, 241 responses were dropped because they did not meet the study requirements. The responses were dropped due to incomplete filling of the questionnaire $(n=98)$, completed by male respondents $(n=13)$, or took unrealistic time to complete $(n=130)$. The unrealistic time was either too short (less than $5 \mathrm{~min}$ ) or too long (more than one hour). We dropped surveys that took too long to complete due to the nature of this study that requires participants to respond to questions while taking the preferred social media platform and fashion brand in consideration. Thus, after deleting surveys that do not meet requirement, we ended up with 464 surveys for analysis.

We used a 5-point Likert scales ranged from ' 1 ' (strongly disagree) to ' 5 ' (strongly agree). To measure SMMa (secondorder), we adopted Kim and Ko's (2010) multidimensional
Table 4 Measurement model evaluation for higher-order formative constructs

\begin{tabular}{llll}
\hline Higher-order Formative Construct & First-order Reflective constructs & VIF & Weight \\
\hline Social Media Marketing Activities & Customization & 2.514 & $0.249^{* * *}$ \\
SMMA & Trendiness & 3.491 & $0.354^{* * *}$ \\
& Interaction & 1.923 & $0.405^{* * *}$ \\
& Entertainment & 2.395 & $0.295^{* * *}$ \\
Lovemark & Brand Love & 4.216 & $0.741^{* * *}$ \\
& Brand Respect & 3.685 & $0.555^{* * *}$ \\
Community Engagement & Affective Community Engagement & 3.447 & $0.330^{* * *}$ \\
& Cognitive Community Engagement & 3.467 & $0.338^{* * *}$ \\
& Behavioral Community Engagement & 3.390 & $0.474^{* * *}$ \\
\hline
\end{tabular}

Significance level: $* * * \mathrm{p}<0.001$ 
Table 5 PLS Results for

Structural Model

\begin{tabular}{|c|c|c|c|c|c|c|}
\hline \multirow[t]{2}{*}{ Exogenous Constructs } & \multicolumn{2}{|l|}{ Lovemark } & \multicolumn{2}{|l|}{ ComEng } & \multicolumn{2}{|c|}{ Brand Loyalty } \\
\hline & $\beta$ & $\mathrm{t}$-value & $\beta$ & t-value & $\beta$ & t-value \\
\hline SMMa & $0.68 * * *$ & 17.60 & $0.379 * * *$ & 9.24 & 0.045 & 0.63 \\
\hline Lovemark & & & & & $0.282 * * *$ & 3.79 \\
\hline ComEng & & & & & $0.411^{* * *}$ & 9.11 \\
\hline $\mathrm{R}^{2}(\%)$ & $44.60 \%$ & & $14.40 \%$ & & $41.60 \%$ & \\
\hline
\end{tabular}

Significance level: $* * * \mathrm{p}<0.001$ scale, which consists of five sub-dimensions. For instance, we used two items to measure entertainment, two items to measure, customisation, for interaction we used three items, eWOM was measured based on two items and trendiness measured through two items. To measure community engagement (second-order, reflective-reflective), we adopted Algharabat and Rana (2020) and Dessart (2017) scale which consists of three sub-dimensional constructs; cognitive engagement with six items, affection engagement with six items, and behavioural engagement with 10 items. Furthermore, we measured lovemark (second-order) based on sub-dimensional constructs based on Roberts (2005). For instance, we measured brand love with five items, and brand respect with eight items. To measure brand loyalty, we adopted the scale of Walsh et al. (2009) and Yoo and Donthu (2001) which consists of five items (Appendix 2). We have developed this study questionnaire in English language and then we got it translated back into Arabic language (Brislin, 1976).

\subsection{Data Analysis}

We used partial least squares structural equation modelling (PLS-SEM, SmartPLS 3.03 software) to test our research hypotheses (Hair et al., 2014; Ringle et al., 2015). Hair et al. (2014) assert that PLS is suitable for testing causal relationships which derived from theories using hypotheses and empirical data. We have used PLS method to test our model for the following considerations as explained by Hair et al. (2014): (i) one of the goals of the current study is to anticipate the main drivers of SMMa; lovemark, community engagement (as second-order construct) and brand loyalty (as first-order construct). (ii) Testing such a model will make the structural model which consists of 11 constructs and its 45 indicators. Furthermore, the current study has a sample size of 464 valid participants. This sample size reflects the role of being minimally 10 times larger than the largest number of structural paths. Thus, using PLS in this case is recommended (Hair et al., 2014).

Results of the EFA with varimax rotation shows that the measurement items in the current study are fairly connected to each related construct. Furthermore, the test of Kaiser-Meyer - Olkin shows a good result (0.9, Sharma,
1996). Thus, our data is fit to move further for confirmatory factor analysis (CFA). Moreover, we find that all the items of our different constructs loaded above 0.5 , except for some items (Costello \& Osborne, 2005). For instance, we eliminated eWOM construct with all its items (eWOM1 and eWOM2), as well as we deleted five items from brand respect (BR1, $\mathrm{BR} 3, \mathrm{BR} 5, \mathrm{BR} 7$, and $\mathrm{BR} 8$ ), one item from affective engagement (AEG1), and one item form behavioural engagement (BEG10) (Henseler et al., 2009). We find that fit indices were suitable as well for measurement model. For instance, we find NFI (0.88) and SRMR (0.05) all supporting an acceptable fit (Hair et al., 2014; Ziggers \& Henseler, 2016) using PLS-SEM.

\section{Results}

\subsection{Measurement Model}

Our model consisting of reflective and formative constructs. Thus, for the reflective constructs we followed Hair et al.'s (2014) recommendation and hence reported convergent validity, internal consistency and discriminant validity. For instance, to measure internal consistency we employed two criteria i.e., Cronbach's Alpha ( $\alpha)$ and composite reliability $(\mathrm{CR})$. Table 1 shows that the values of Cronbach's Alpha $(\alpha)$ and composite reliability exceed 0.70 for all latent variables. This result supports previous research (Hair et al., 2014; Mackenzie et al., 2011) recommendations regarding internal consistency. Furthermore, to test convergent validity, we followed two criteria, namely, indicator reliability and average variance extracted (AVE). AVE values exceeded 0.50 and items loadings were above 0.7 , indicating convergent validity (see Table 2) (Hair et al., 2014; Mackenzie et al., 2011). According to Henseler et al. (2009), loadings below 0.40 should not be taken for further analysis. Yet, we find that all our items loaded above this threshold in the measurement model.

To test discriminant validity, we used two criteria. First, square root of AVE, and the Hetrotrait - Monotrait Ratio (HTMT). Our results show that the square root of the AVE was greater than its correlation with any other construct (Table 2) (Fornell \& Larcker, 1981). Second, the HTMT 
ratios were below 0.90 (Henseler et al., 2015) (Table 3). Thus, following the results of the two criteria, we conclude that this research has no problem with discriminant validity (Tables 2 and 3 ).

For the formative constructs, we followed previous research (Becker et al., 2012; Ringle et al., 2012) assumption to measure a higher-order construct of a reflective-formative type. Thus, we relied on multicollinearity, significance and sign of the weights. To assess multicollinearity, we used variance inflation factor (VIF). Our results show that VIF values range from 1.923 to 4.216 , indicating noncollinearity issues because the values are below '5' (Hair et al., 2014). Moreover, our results show that all the weights are positive and significant $(\mathrm{p}<0.01)$ (Table 4) (Hair et al., 2014).

\subsection{Common Method Bias}

We followed Harman's single factor method to test common method bias. Harman's single factor test is based on including all the research items together and then running an exploratory factor analysis with an unrotated factor solution. Our results show that the first factor calculated for $33.4 \%$ of the variance. Thus, according to Podsakoff et al. (2003), this is less than $50 \%$ of the variance that is acceptable and hence no concerns were found about common method bias.

\subsection{Structural Model}

To test our research framework, we used structural model path coefficients. In particular, we followed Hair et al.'s (2014) recommendations which focused on conducting four tests: (1) coefficient of determination $\left(\mathrm{R}^{2}\right)$ to measure predictive power of our model, (2) effect size $\left(f^{2}\right)$, predictive relevance $\left(\mathrm{Q}^{2}\right)$ and structural model path coefficients.

Our results show that the values of $\mathrm{R}^{2}$ for community engagement (0.144), lovemark (0.445), and brand loyalty (0.416). All $\mathrm{R}^{2}$ values were considered acceptable (Hair et al., 2014; Henseler et al., 2009). Both lovemark (0.445) and brand loyalty (0.416) obtained moderate $\mathrm{R}^{2}$ values (Hair et al., 2014). However, community engagement counts for a value of 0.144 which considered as a weak value (Hair et al., 2014). $f^{2}$ results revealed some significant impacts. For instance, some of the values yield large effect such as SMMa on lovemark $\left(f^{2}=0.806\right)$. Others yield small effects such as community engagement on brand loyalty $\left(f^{2}=0.193\right)$, SMMa on community engagement $\left(f^{2}=0.168\right)$. While we find that the impact of lovemark on brand loyalty $\left(f^{2}=0.058\right)$ and SMMa on brand loyalty $\left(f^{2}=0.002\right)$ are not only non-significant but also yield effect $\left(f^{2}\right.$ less than $\left.=0.02\right)$ (Cohen, 1988). To test $Q^{2}$, we used blind folding technique in which we omitted distance set to 7 . We find that all of the $\mathrm{Q}^{2}$ values for the four endogenous variables were above zero. The values ranged as follows (from $\mathrm{Q}^{2}=0.138$ to 0.442 ) (community engagement $=0.138$, brand loyalty $=0.401$, lovemark $=0.442$ ). To test our hypotheses, we run PLS using bootstrapping technique with 1,000 iterations (Hair et al., 2014). Our results revealed that all the proposed hypotheses were supported. Furthermore, our model explain 44.50 per cent of variation in lovemark, 14.44 per cent of variation in community engagement, and 41.60 per cent of variation in brand loyalty. We find that SMMa significantly impacts community engagement $\left(\mathrm{H}_{\mathrm{a}}, \beta=0.379^{* * *}\right.$, $\mathrm{p}<0.001)$. However, we find that SMMa relationship and brand loyalty is non- significant $\left(\mathrm{H} 1_{\mathrm{b}}, \beta=0.045, \mathrm{p}<0.1\right)$. SMMa significantly influences lovemark $\left(\mathrm{H} 1_{c}, \beta=0.68^{* * *}\right.$, $\mathrm{p}<0.001)$. Further, we find that community engagement significantly impacts brand loyalty $\left(\mathrm{H} 2, \beta=0.411^{* * *}\right.$, $\mathrm{p}<0.001)$ and lovemark significantly impacts brand loyalty (H3, $\left.\beta=0.282^{* * *}, \mathrm{p}<0.001\right)$. Table 5 shows PLS results for structural model.

\section{Discussion}

The current research aims to examine the influence of SMMa on community engagement, lovemark and brand loyalty. Furthermore, the current research aims to examine the impact of community engagement and lovemark on brand loyalty within luxury fashion brands industry using SNSs with a focus on Qatari females as an audience. Our findings show that SMMa, community engagement and lovemark are all second-order constructs. For instance, we find that SMMa for luxury fashion brands consist of four constructs; customization, trendiness, interaction and entertainment. However, in line with previous research (Cheung et al., 2020a, b; Liu et al., 2021), we find that eWOM has not been considered as a construct which can be measured via SMMa for luxury fashion brands. This result can be justified as eWOM construct is reflected in community engagement as well as brand loyalty. We find that lovemark is a second-order construct, which comprises of two sub-dimensional constructs, namely, lovemark and brand respect within luxury fashion brands context over SNSs platform. This result is supported by extant literature (Albert et al., 2008; Algharabat, 2017; Carroll \& Ahuvia, 2006; Giovanis \& Athanasopoulou, 2018; Frei \& Shaver, 2002; Roberts, 2005; Zacchilli et al., 2009), which investigated this notion over both offline as well as online contexts.

For community engagement, we find that this construct is a second order one comprises of three sub-dimensional constructs, namely, activation, affective and behavioural. This result comes in accordance with the limited research which has been investigating community engagement as one type of social media engagement (Algharabat \& Rana, 2020; Dessart, 2017; Giertz et al., 2021). In support of hypotheses $\mathrm{H} 1 \mathrm{a}$ and H1c, we find that SMMa has a positive impact 
on both community engagement and lovemark. Our results show a path coefficient value between SMMa and community engagement $(\mathrm{H} 1 \mathrm{a})$ is 0.379 , indicating that females who are interested in luxury fashion brands and using SNSs have a high level of engagement at the community level. For instance, the females are following the main activities that they can get from SNSs in terms of interacting with other females, customizing the services and brands, following trendy fashion, as well as getting more entertainment by following the latest in the luxury fashion brands. Thus, all the activities provided for the female customers via SNSs often enhances their engagement with luxury fashion brands community. This finding is in line with Cheung et al. (2020a, b) study which posits the positive relationship between SMMa (i.e., interaction, eWOM, and trendiness) and engagement. Furthermore, the current result comes in accordance with extant literature (Chan et al., 2014; Dessart et al., 2015; Gallaugher \& Ransbotham, 2010; Hollebeek et al., 2014; Ismail, 2017; Liu et al., 2021).

In support for H1c, we find that a significant relationship SMMa and lovemark construct with coefficient value of 0.68 . This result demonstrates a significant role, which SMMa has in improving lovemark. Our result reveals that SMM activities (interaction, customization, trendiness, and entertainment) within luxury fashion brands allow Qatari females to follow the latest in the luxury fashion brands via SNSs and thus enhance their lovemark for the selected brands. For instance, Qatari females' ability to interact with other females, to customize the services and brands, to follow the latest fashion trend, and to get more entertainment by following the latest in the luxury fashion brands area in SNSs ends up by increasing females love for their preferred brands as well as to respect their brands (the two dimensions of lovemark). Therefore, we believe that SMMa dimensions positively influence brand love (affect) and brand respect (cognitive) aspects of females' lovemark.

This result distinguishes the current research, as we find limited research that investigated this relationship directly within social media context. However, to certain aspects our results are aligned with previous research. For instance, considering Facebook context, Algharabat (2017) reported the positive relationship between SMMa and brand love and Wallace et al. $(2014,2017)$ supported the impact of selfexpressive brands on brand love. In the other context, Huber et al. (2015) find a positive relationship between utilitarian, hedonic values and brand love. However, the studies of Algharabat (2017), Wallace et al. (2017) and Huber et al. (2015) did not investigate the influence of SMMa on the two-dimensions of lovemark.

We find that SMMa has no impact on brand loyalty with coefficient value of 0.045 . Therefore, $\mathrm{H} 1 \mathrm{~b}$ was not supported. The full mediation of SMMa on brand loyalty through community engagement and lovemark indicates that community engagement and lovemark are a conduit of the effect of SMMa on brand loyalty and that in absence of these mediators SMMa is unrelated to brand loyalty (Holland et al., 2017). Even though our results for $\mathrm{H} 1 \mathrm{~b}$ was contradicted with previous research (e.g., Algharabat, 2017; Bruhn et al., 2012; Kim \& Ko, 2012; Godey et al., 2016), we still have justifications for this non-significant relationship. For instance, Algharabat's (2017) study was not about luxury fashion brands. Kim and Ko (2012) linked SMMa with brand equity which measured via unidimensional construct and included some questions regarding brand loyalty. Godey et al. (2016) linked SMMa with brand equity (second-order) which was measured via brand awareness and brand image but not brand loyalty. Another justification for this nonsignificant relationship could be attributed to the fact that within luxury fashion brands, SMMa could be reflective in both lovemark and community engagement, which have positive relationships with brand loyalty. However, in our study, Qatari females believe that the presence of lovemark (with its two dimensions; brand love and brand respect) and community engagement (with its three dimensions; affect, cognitive and behavioural) are the only reasons for the effect of SMMa on brand loyalty. These significant mediating relationships make a lot of sense as customers' social media marketing activities conducted through eWOM, customization, trendiness, entertainment and interaction alone are not enough to influence their loyalty in the absence of love, passion and creative community engagement.

We found that the relationship between community engagement and brand loyalty was maintained (H2) with coefficient value of 0.411 , indicating that Qatari female customers who are using SNSs to follow the latest luxury fashion brands have a high level of community engagement with its three dimensions. For instance, Qatari females who are part of SNSs communities for luxury fashion brands use such communities to express their thoughts and will influence and be influenced by other members. Such community will influence the way Qatari females feel and behave. Hence, as a result, we find that community engagement impacts brand loyalty. This result comes in accordance with the previous research in this area. For instance, Dwivedi (2015) reported the affirmative relationship between engagement (cognitive processing, affection and activation) and brand loyalty. Algharabat et al. (2020) reported the positive relationship between community engagement (second-order construct) and brand loyalty. Furthermore, extant literature (Alalwan et al., 2019; Hollebeek et al., 2014; Hollebeek, 2011a; Leckie et al., 2016; Vivek et al., 2012) reported the positive relationship between engagement dimensions (consumers' cognitive processing, affective part) and brand loyalty.

We found that the relationship between lovemark and brand loyalty comes to our expectations. Thus, our results 
supported the significance of this relationship (H3) with path coefficient value of 0.282 . Accordingly, the result indicates that Qatari females using SNS pages for luxury fashion brands love and respect their brands and hence as a result Qatari females have loyalty towards such luxury fashion brands (Zhang et al., 2021). Thus, the notion of lovemark helps improving Qatari females' brand relationships in particular loyalty. This result comes in line with previous research (Chen et al., 2020; Giovanis \& Athanasopoulou, 2018; Veloutsou \& Aimpitaksa, 2017), which finds a positive relationship between lovemark and brand loyalty.

\subsection{Implications for Theory}

Our research has contributed to the extant literature within social media marketing in the following ways: First, extant literature has not connected or proposed the linkage between our tested constructs as we accomplished in the current research. Our research model linked SMMa (higher-order formative), community engagement (higher-order formative), lovemark (higher-order formative), and brand loyalty. Extant literature has empirically tested some of the linkages of our proposed constructs but not all of them. For instance, Algharabat (2017) linked SMMa with brand love, but not lovemark. Furthermore, within the context of linking lovemark with brand loyalty, previous research (Chen et al., 2020; Giovanis \& Athanasopoulou, 2018; Veloutsou \& Aimpitaksa, 2017) linked lovemark and brand loyalty but not community engagement with brand loyalty. Moreover, within the context of SMMa, no study has investigated the linkage between SMMa and community engagement.

What has been done in this area are attempts to empirically link SMMa with customer-brand engagement (Cheung et al., 2020a, b), or linking SMMa with brand engagement in self-concept (Nyadzayo et al., 2020). Hence, we consider the current research model as a contribution to present literature by empirically testing a framework, which has not been tested before. The way we decided to use such constructs within fashion brands considered important as many users of SNSs started their activities via SMM activities, as consumers develop their relationship with the fashion brand they start being engaged with brand and love and respect the brand that will end up with being loyal to the fashion brand. Second, this research considered among the few research which has focused on one type of social media engagement, namely, community engagement (Algharabat \& Rana, 2020; Dessart, 2017).

Therefore, examining a precise type of engagement is considered in addition to the body of literature. Extant research on the area of engagement investigated different types of engagement (Hollebeek et al., 2014; Vivek et al., 2012; Wirtz et al., 2013) but not community engagement. The two main studies which focused on the area of community engagement are Algharabat and Rana (2020) and Dessart (2017). Accordingly, we added to the extant literature more empirical studies which centred on community engagement. Third, the context of the current study considered another contribution. We focused our efforts on luxury fashion brands, SNSs as a social media and females. We have examined a new context of Middle Eastern country through this research.

Furthermore, collecting the data from females using who are using SNS platforms considered as another contribution. As the majority of study collected the data either from different platforms (Facebook, Twitter) or local social media (WeChat), none of the previous studies focused solely on females. Thus, within this context a little is known about females' behaviour. Fourth, while investigating the relationships between our research model constructs, we used higher-order formative constructs to test SMMa, lovemark and community engagement. This way of testing the constructs is an addition to the extant research. For instance, extant research linked the elements of SMMa (first-order reflective) with lovemark (first-order reflective) and community engagement (first-order reflective). However, none of the extant research investigated the relationships between SMMa, lovemark, and community engagement as higher-order formative constructs. Thus, using higherorder formative constructs in this research is yet another contribution. Fifth, conducting our study in a non-Western context and focusing on females who are passionate about luxury fashion brands adds to literature some insights that could be reflected in developing countries. As a result, we believe that the above contributions can add more on scholarly research within the IS area. Linking the notion of lovemark with other constructs, which come from the IS area would contribute and add to the literature within IS area by giving evidence on the importance of adopting the notion of lovemark in social media pages, which focused on luxury fashion brands.

\subsection{Implications for Practice}

The vital role of SMMa dimensions (customization, trendiness, interaction and entertainment) within SNS luxury fashion brand pages targeting females in a non-Western context and the linkages of SMMa dimensions with lovemark dimensions (brand love and brand respect), community engagement dimensions (affective, cognitive, and behavioural) and brand loyalty make it beneficial for SNS practitioners. Thus, our results have the following implications for practitioners, IS managers and marketing strategists who are planning to achieve their goals in SNS luxury fashion brand pages. First, IS managers who seek to build strong brand relationship with their users using SNSs should take advantage of SMMa. The main activities that we find out of 
luxury fashion brand pages in this research are; customization, trendiness, interaction and entertainment.

Furthermore, we find that such activities are important to enhance both lovemark with its dimensions (brand love and brand respect) and community engagement dimensions (affect, cognitive and behavioural). Thus, within SNS pages, which are designed to reflect the luxury fashion brands, IS managers and marketing strategists should design such pages to have more entertainment in terms of hedonic values such as more vivid picture and maybe the use of virtual reality models. Customization could be utilized more via virtual reality model. Therefore, we believe that luxury fashion brand managers should focus on different SMM activities for luxury fashion brands on SNSs and they should invest on SMMa to reflect females' brand love and brand respect. Focusing on SMMa will encourage females to communicate with other females to express their interest with the luxury fashion brands, to interact and to inform others about the main associations of their brand via sharing their stories.

SMM activities also help luxury fashion brand managers in SNSs to build females community engagement. Therefore, we recommend IS and marketing managers to use different technological tools to help females' customers to customize their fashion brands, to interact with their community members, to make their experience more entertained and make the fashion brand trendy. Furthermore, we believe that trendiness is an effective tool that enhance females to continuously visiting luxury fashion brand pages to mirror the latest fashion, to attract females' attention, and thus to increase their engagement at the affective, cognitive and behavioural levels. Doing this will increase female engagement via SNSs community, which is tailored for luxury fashion brands. Thus, IS managers and strategists who are planning to increase their community engagement should encourage female users to spread the positive word-of-mouth regarding their luxury fashion brands. Finally, we recommend brand strategists to flow up their female users to maintain a strong relationship with them as this can be the key to keep them loyal to luxury fashion brands companies' via focusing more on lovemark and community engagement dimensions. IS managers can benefit from the results of the current research within luxury fashion brand, as to the best of the authors' knowledge this is the first research, which linked the notion of lovemark with existing constructs that comes from the IS area. Therefore, IS managers should focus more on designing and developing their content via social media platforms to connect SMMa with community engagement. Doing this will enhance user's interactivity and co-creation and thus enhance users' brand loyalty.

\subsection{Limitations and Future Research Directions}

The current research has some limitations. First, generalizing the results of this research is one of the main limitations (Rana \& Dwivedi, 2016). We have conducted this research in a Middle Eastern context (even though Qatar citizens have the highest personal income in the whole world). Thus, we cannot generalize the results to other Middle Eastern countries as well as Western countries. Therefore, we recommend future research to conduct other studies in both contexts. Second, our findings were related to the area of luxury fashion brands within social media context. Thus, we have no idea regarding other sectors. Further studies should consider other sectors such as masstige brand, clothing sectors, and cosmetics. Third, we conducted this study via following cross-sectional method. Thus, we recommend the future research as a longitudinal study to chase any temporal changes in the proposed constructs. Fourth, we conducted this research using SNSs. Thus, future research might investigate our model using other social media platforms such as Twitter or Facebook (Alalwan et al., 2017; Kapoor et al., 2018). Finally, the future research could consider investigating more constructs such as the antecedents of lovemark and link them with lovemark and community engagement (Roberts, 2005; Tamilmani et al., 2021). The other future research avenue may be to investigate the impact of privacy calculus (Najjar et al., 2021) on engagement.

\section{Conclusions}

The purpose of this research was to examine the impact of SMMa on community engagement and lovemark and their further influence on brand loyalty. Prior research (e.g., Godey et al., 2016) investigated the use of only two SNSs namely Facebook and Twitter. However, we contend that collecting data from customers on a specific SNS may not match consumer behavior in real life as consumers have accounts on various SNSs and some of these are more preferable compared to others. Therefore, we examined the influence of SMMa on community engagement and lovemark using social networking sites (such as Facebook, Instagram, Snapchat, and Twitter), which have pages for luxury fashion brands. The proposed research model was based on the underlying theories including lovemark theory, engagement theory and brand equity theory. The findings indicated that SMMa positively influences community engagement and lovemark. Moreover, we find positive relationships between community engagement, lovemark and brand loyalty. However, it was also found that SMMa has no direct influence on brand loyalty. 
Appendix 1. Demographics for the study

Table 6 Preferred SNS Platforms in sample

\begin{tabular}{llr}
\hline Social Media Platform & Frequency & Percent \\
\hline Facebook & 2 & $0.4 \%$ \\
Instagram & 355 & $76.5 \%$ \\
Snapchat & 73 & $15.7 \%$ \\
Twitter & 19 & $4.1 \%$ \\
Other & 15 & $3.2 \%$ \\
\hline
\end{tabular}

Table 7 Participant demographic

\begin{tabular}{|c|c|c|c|}
\hline Characteristics & Description & Frequency & Percent \\
\hline \multirow{3}{*}{$\begin{array}{l}\text { Social Media } \\
\text { Platform Tenure } \\
\text { (years) }\end{array}$} & Less than 1 year & 19 & $4.1 \%$ \\
\hline & From 1 to 3 years & 71 & $15.3 \%$ \\
\hline & From 4 to 6 years & 152 & $32.8 \%$ \\
\hline \multirow{5}{*}{$\begin{array}{l}\text { Social Media Plat- } \\
\text { form time spent/ } \\
\text { day (In hours) }\end{array}$} & Less than $1 \mathrm{~h}$ & 48 & $10.3 \%$ \\
\hline & From 1 to $3 \mathrm{~h}$ & 167 & $36 \%$ \\
\hline & From 4 to $6 \mathrm{~h}$ & 146 & $31.5 \%$ \\
\hline & More than $6 \mathrm{~h}$ & 103 & $22.2 \%$ \\
\hline & Less than $1 \mathrm{~h}$ & 48 & $10.3 \%$ \\
\hline \multirow{5}{*}{$\begin{array}{l}\text { Annual Family } \\
\text { Income (In thou- } \\
\text { sand dollars) }\end{array}$} & Less than 20 & 41 & $8.8 \%$ \\
\hline & From 20 to 40 & 105 & $22.6 \%$ \\
\hline & From 41 to 60 & 89 & $19.2 \%$ \\
\hline & From 61 to 80 & 58 & $12.5 \%$ \\
\hline & More than 80 & 171 & $36.9 \%$ \\
\hline \multirow{7}{*}{$\begin{array}{l}\text { Annual spending on } \\
\text { fashion brands (In } \\
\text { thousand dollars) }\end{array}$} & Less than 5 & 90 & $19.4 \%$ \\
\hline & From 5 to 10 & 132 & $28.4 \%$ \\
\hline & From 11 to 15 & 65 & $14 \%$ \\
\hline & From 16 to 20 & 63 & $13.6 \%$ \\
\hline & From 21 to 25 & 33 & $7.1 \%$ \\
\hline & From 26 to 30 & 37 & $8 \%$ \\
\hline & More than 30 & 44 & $9.5 \%$ \\
\hline \multirow{8}{*}{$\begin{array}{l}\text { Respondent age (In } \\
\text { years) }\end{array}$} & From 18 to 23 & 217 & $46.8 \%$ \\
\hline & From 24 to 29 & 138 & $29.7 \%$ \\
\hline & From 30 to 35 & 65 & $14 \%$ \\
\hline & From 36 to 41 & 20 & $4.3 \%$ \\
\hline & From 42 to 47 & 14 & $3 \%$ \\
\hline & From 48 to 53 & 7 & $1.5 \%$ \\
\hline & From 54 to 59 & 2 & $0.4 \%$ \\
\hline & 60 or more & 1 & $0.2 \%$ \\
\hline
\end{tabular}

Table 8 Preferred luxury fashion brands

\begin{tabular}{llr}
\hline Luxury Brand & Frequency & Percent \\
\hline Alexander McQueen & 6 & $1.3 \%$ \\
Armani & 22 & $4.7 \%$ \\
Burberry & 9 & $1.9 \%$ \\
Carolina Herrera & 6 & $1.3 \%$ \\
Chanel & 91 & $19.6 \%$ \\
Christian Louboutin & 5 & $1.1 \%$ \\
Dior & 78 & $16.8 \%$ \\
Dolce \& Gabbana & 40 & $8.6 \%$ \\
Givenchy & 10 & $2.2 \%$ \\
Gucci & 53 & $11.4 \%$ \\
Hermes & 55 & $11.9 \%$ \\
Louis Vuitton & 48 & $10.3 \%$ \\
Marc Jacobs & 1 & $0.2 \%$ \\
Michael Kors & 4 & $0.9 \%$ \\
Ralph Lauren & 6 & $1.3 \%$ \\
Saint Laurent & 2 & $0.4 \%$ \\
Tory Burch & 8 & $1.7 \%$ \\
Valentino & 10 & $2.2 \%$ \\
Versace & 10 & $2.2 \%$ \\
\hline
\end{tabular}

Table 9 Number of preferred luxury fashion brands followers up to November 2021

\begin{tabular}{llll}
\hline Luxury Brand & Instagram & Twitter & Facebook \\
\hline Alexander McQueen & $11.5 \mathrm{~m}$ & $1.8 \mathrm{~m}$ & $2.2 \mathrm{~m}$ \\
Armani & $2.9 \mathrm{~m}$ & $3.5 \mathrm{~m}$ & $8.7 \mathrm{~m}$ \\
Burberry & $18.6 \mathrm{~m}$ & $8.1 \mathrm{~m}$ & $17 \mathrm{~m}$ \\
Carolina Herrera & $5.8 \mathrm{~m}$ & $110.8 \mathrm{~m}$ & $3.7 \mathrm{~m}$ \\
Chanel & $47.5 \mathrm{~m}$ & $13.3 \mathrm{~m}$ & $23 \mathrm{~m}$ \\
Christian Louboutin & $14.7 \mathrm{~m}$ & $2.8 \mathrm{~m}$ & $3.5 \mathrm{~m}$ \\
Dior & $38.3 \mathrm{~m}$ & $8.6 \mathrm{~m}$ & $18.4 \mathrm{~m}$ \\
Dolce \& Gabbana & $27 \mathrm{~m}$ & $5.3 \mathrm{~m}$ & $12 \mathrm{~m}$ \\
Givenchy & $14.8 \mathrm{~m}$ & $1 \mathrm{~m}$ & $2.7 \mathrm{~m}$ \\
Gucci & $46.3 \mathrm{~m}$ & $6.5 \mathrm{~m}$ & $20 \mathrm{~m}$ \\
Hermes & $11.2 \mathrm{~m}$ & $108.6 \mathrm{~m}$ & $3.6 \mathrm{~m}$ \\
Louis Vuitton & 46.4 & $9.1 \mathrm{~m}$ & $24 \mathrm{~m}$ \\
Marc Jacobs & $1.6 \mathrm{~m}$ & $8.6 \mathrm{~m}$ & $2.2 \mathrm{~m}$ \\
Michael Kors & 16.7 & $3.3 \mathrm{~m}$ & $18 \mathrm{~m}$ \\
Ralph Lauren & $13.1 \mathrm{~m}$ & $2.2 \mathrm{~m}$ & $9.3 \mathrm{~m}$ \\
Saint Laurent & $9.6 \mathrm{~m}$ & $4.8 \mathrm{~m}$ & $3.3 \mathrm{~m}$ \\
Tory Burch & $2.9 \mathrm{~m}$ & 9880 & $2.3 \mathrm{~m}$ \\
Valentino & $15.7 \mathrm{~m}$ & $2.1 \mathrm{~m}$ & $3.2 \mathrm{~m}$ \\
Versace & $25.5 \mathrm{~m}$ & $5 \mathrm{~m}$ & $6.7 \mathrm{~m}$ \\
\hline
\end{tabular}




\section{Appendix 2. Measurement items}

\begin{tabular}{|c|c|c|}
\hline $\begin{array}{l}\text { Construct I } \\
\text { Dimensions }\end{array}$ & Measures & Source(s) \\
\hline $\begin{array}{l}\text { Social media } \\
\text { marketing } \\
\text { activities }\end{array}$ & $\begin{array}{l}\text { EWOM1: I pass information } \\
\text { on luxury fashion brands } \\
\text { in my SNS platform }\end{array}$ & $\begin{array}{l}\text { Godey et al. (2016); } \\
\text { Kim and Ko (2012) }\end{array}$ \\
\hline $\begin{array}{l}\text { Word of mouth } \\
\text { (EWOM1- } \\
\text { EWOM2) }\end{array}$ & $\begin{array}{l}\text { EWOM2: I upload the } \\
\text { content of luxury fashion } \\
\text { brands in my SNS plat- } \\
\text { form }\end{array}$ & \\
\hline \multirow[t]{2}{*}{$\begin{array}{l}\text { Customization } \\
\text { (CUST1- } \\
\text { CUST2) }\end{array}$} & $\begin{array}{l}\text { CUST1: The luxury fashion } \\
\text { brand enables me to easily } \\
\text { search for the information } \\
\text { I want on SNS platform }\end{array}$ & $\begin{array}{l}\text { Godey et al. (2016); } \\
\text { Kim and Ko (2012) }\end{array}$ \\
\hline & $\begin{array}{l}\text { CUST2: The luxury fashion } \\
\text { brand enables me to easily } \\
\text { customize the services I } \\
\text { want on SNS platform }\end{array}$ & \\
\hline \multirow[t]{2}{*}{$\begin{array}{l}\text { Trendiness } \\
\text { (TRE1- } \\
\text { TRE2) }\end{array}$} & $\begin{array}{l}\text { TRE1: The luxury fashion } \\
\text { brands on SNS platform } \\
\text { allows me sharing the lat- } \\
\text { est information with others }\end{array}$ & $\begin{array}{l}\text { Godey et al. (2016); } \\
\text { Kim and Ko (2012) }\end{array}$ \\
\hline & $\begin{array}{l}\text { TRE2: Using luxury fashion } \\
\text { brands on SNS is trendy }\end{array}$ & \\
\hline \multirow[t]{3}{*}{$\begin{array}{l}\text { Interaction } \\
\text { (INT1-INT3) }\end{array}$} & $\begin{array}{l}\text { INT1: Luxury fashion brand } \\
\text { enables information-shar- } \\
\text { ing with others on the SNS } \\
\text { platform }\end{array}$ & $\begin{array}{l}\text { Godey et al. (2016); } \\
\text { Kim and Ko (2012) }\end{array}$ \\
\hline & $\begin{array}{l}\text { INT2: It is possible to } \\
\text { have conversations or to } \\
\text { exchange opinions with } \\
\text { others on the luxury } \\
\text { fashion brands on SNS } \\
\text { platform }\end{array}$ & \\
\hline & $\begin{array}{l}\text { INT3: I give my opinion } \\
\text { easily through the brand } \\
\text { page of luxury fashion } \\
\text { brands on SNS platform }\end{array}$ & \\
\hline \multirow[t]{2}{*}{$\begin{array}{l}\text { Entertainment } \\
\text { (ENT1- } \\
\text { ENT2) }\end{array}$} & $\begin{array}{l}\text { ENT1: it is fun to use luxury } \\
\text { fashion brand pages on } \\
\text { SNS platform }\end{array}$ & $\begin{array}{l}\text { Godey et al. (2016); } \\
\text { Kim and Ko (2012) }\end{array}$ \\
\hline & $\begin{array}{l}\text { ENT2: The content of } \\
\text { luxury fashion brands } \\
\text { pages on SNS platform } \\
\text { seems interesting }\end{array}$ & \\
\hline \multirow[t]{4}{*}{$\begin{array}{l}\text { Lovemark } \\
\text { Brand Love } \\
\text { (BLO1- } \\
\text { BLO5) }\end{array}$} & $\begin{array}{l}\text { BLO1: I love luxury fashion } \\
\text { brand page on SNS } \\
\text { platform }\end{array}$ & $\begin{array}{l}\text { Algharabat (2017); } \\
\text { Carroll and Ahuvia } \\
\text { (2006); Roberts } \\
\text { (2005) }\end{array}$ \\
\hline & $\begin{array}{l}\text { BLO2: Luxury fashion } \\
\text { brand on SNS platform is } \\
\text { a pure delight }\end{array}$ & \\
\hline & $\begin{array}{l}\text { BLO3. Luxury fashion } \\
\text { brand on SNS platform is } \\
\text { totally awesome }\end{array}$ & \\
\hline & $\begin{array}{l}\text { BLO4. Luxury fashion } \\
\text { brand on SNS platform } \\
\text { makes me feel good }\end{array}$ & \\
\hline
\end{tabular}

\begin{tabular}{|c|c|c|}
\hline $\begin{array}{l}\text { Construct I } \\
\text { Dimensions }\end{array}$ & Measures & Source(s) \\
\hline & $\begin{array}{l}\text { BLO5. Luxury fashion } \\
\text { brand on SNS platform is } \\
\text { a wonderful brand }\end{array}$ & \\
\hline \multirow{8}{*}{$\begin{array}{l}\text { Lovemark } \\
\text { Brand Respect } \\
\text { (BR1-BR8) }\end{array}$} & $\begin{array}{l}\text { BR1. I respect Luxury fash- } \\
\text { ion brand on SNS platform }\end{array}$ & Roberts (2005) \\
\hline & $\begin{array}{l}\text { BR2. Luxury fashion brand } \\
\text { on SNS platform brand is } \\
\text { honest to me }\end{array}$ & \\
\hline & $\begin{array}{l}\text { BR3. Luxury fashion brand } \\
\text { on SNS platform commu- } \\
\text { nicates well with me }\end{array}$ & \\
\hline & $\begin{array}{l}\text { BR4. Luxury fashion brand } \\
\text { on SNS platform is very } \\
\text { faithful }\end{array}$ & \\
\hline & $\begin{array}{l}\text { BR5. I approve luxury } \\
\text { fashion brand performance } \\
\text { on SNS platform } \dagger\end{array}$ & \\
\hline & $\begin{array}{l}\text { BR6. I'm very committed } \\
\text { to luxury fashion brand on } \\
\text { SNS platform } \dagger\end{array}$ & \\
\hline & $\begin{array}{l}\text { BR7. Luxury fashion brand } \\
\text { on SNS platform leads } \\
\text { fashion trend season to } \\
\text { season } \dagger\end{array}$ & \\
\hline & $\begin{array}{l}\text { BR8. Luxury fashion } \\
\text { brand on SNS platform is } \\
\text { responsible to me }\end{array}$ & \\
\hline \multirow{6}{*}{$\begin{array}{l}\text { Community } \\
\text { engagement } \\
\text { Affective } \\
\text { engagement } \\
\text { (AEG1- } \\
\text { AEG6) }\end{array}$} & $\begin{array}{l}\text { AEG1: The community of } \\
\text { luxury fashion brands on } \\
\text { SNS platform makes me } \\
\text { feel enthusiastic }\end{array}$ & $\begin{array}{l}\text { Algharabat and Rana } \\
\text { (2020); Dessart } \\
\text { (2017) }\end{array}$ \\
\hline & $\begin{array}{l}\text { AEG2: The community of } \\
\text { luxury fashion brands on } \\
\text { SNS platform makes me } \\
\text { feel involved about their } \\
\text { issues }\end{array}$ & \\
\hline & $\begin{array}{l}\text { AEG3: I find the com- } \\
\text { munity of luxury fashion } \\
\text { brands on SNS platform } \\
\text { interesting }\end{array}$ & \\
\hline & $\begin{array}{l}\text { AEG4: I feel happy when } \\
\text { interacting with the com- } \\
\text { munity of luxury fashion } \\
\text { brands on SNS }\end{array}$ & \\
\hline & $\begin{array}{l}\text { AEG5: I feel pleasure when } \\
\text { interacting with the com- } \\
\text { munity of luxury fashion } \\
\text { brands on SNS }\end{array}$ & \\
\hline & $\begin{array}{l}\text { AEG6: Interacting to the } \\
\text { community of luxury fash- } \\
\text { ion brands on SNS gives } \\
\text { me a treat }\end{array}$ & \\
\hline $\begin{array}{l}\text { Community } \\
\text { engagement } \\
\text { Cognitive } \\
\text { engagement } \\
\text { (CEG1- } \\
\text { CEG6) }\end{array}$ & $\begin{array}{l}\text { CEG1: I dedicate a consid- } \\
\text { erable time thinking about } \\
\text { the community of luxury } \\
\text { fashion brands on SNS }\end{array}$ & $\begin{array}{l}\text { Algharabat and Rana } \\
\text { (2020); Dessart } \\
\text { (2017) }\end{array}$ \\
\hline
\end{tabular}




\begin{tabular}{|c|c|c|}
\hline $\begin{array}{l}\text { Construct I } \\
\text { Dimensions }\end{array}$ & Measures & Source(s) \\
\hline & $\begin{array}{l}\text { CEG2: I devote time think- } \\
\text { ing about the community } \\
\text { of luxury fashion brand on } \\
\text { SNS platform }\end{array}$ & \\
\hline & $\begin{array}{l}\text { CEG3: I usually immersed } \\
\text { while interacting with my } \\
\text { community members of } \\
\text { luxury fashion brands on } \\
\text { SNS }\end{array}$ & \\
\hline & $\begin{array}{l}\text { CEG4: While interacting } \\
\text { with the members of } \\
\text { luxury fashion brand com- } \\
\text { munity on SNS I do not } \\
\text { feel the time }\end{array}$ & \\
\hline & $\begin{array}{l}\text { CEG5: When I am interact- } \\
\text { ing with the members } \\
\text { of community of luxury } \\
\text { fashion brand on SNS } \\
\text { platform, I get carried } \\
\text { away }\end{array}$ & \\
\hline & $\begin{array}{l}\text { CEG6: It is difficult to sepa- } \\
\text { rate myself while I interact } \\
\text { with community members } \\
\text { of luxury fashion brands } \\
\text { on SNS }\end{array}$ & \\
\hline \multirow{7}{*}{$\begin{array}{l}\text { Community } \\
\text { engagement } \\
\text { Behavioural } \\
\text { engagement } \\
\text { (BEG1- } \\
\text { BEG10) }\end{array}$} & $\begin{array}{l}\text { BEG1: I share my thoughts } \\
\text { with my community of } \\
\text { luxury fashion brand on } \\
\text { SNS }\end{array}$ & $\begin{array}{l}\text { Algharabat and Rana } \\
\text { (2020); Dessart } \\
\text { (2017) }\end{array}$ \\
\hline & $\begin{array}{l}\text { BEG2: I circulate exciting } \\
\text { content with my com- } \\
\text { munity of luxury fashion } \\
\text { brand on SNS }\end{array}$ & \\
\hline & $\begin{array}{l}\text { BEG3: I help my com- } \\
\text { munity of luxury fashion } \\
\text { brand on SNS }\end{array}$ & \\
\hline & $\begin{array}{l}\text { BEG4: I ask members of } \\
\text { luxury fashion brands } \\
\text { community questions on } \\
\text { SNS }\end{array}$ & \\
\hline & $\begin{array}{l}\text { BEG5: I pursue information } \\
\text { or ideas from my com- } \\
\text { munity at luxury fashion } \\
\text { brands on SNS }\end{array}$ & \\
\hline & $\begin{array}{l}\text { BEG6: I ask for aid from } \\
\text { community members at } \\
\text { luxury fashion brands on } \\
\text { SNS }\end{array}$ & \\
\hline & $\begin{array}{l}\text { BEG7: I endorse my com- } \\
\text { munity at luxury fashion } \\
\text { brand on SNS }\end{array}$ & \\
\hline
\end{tabular}

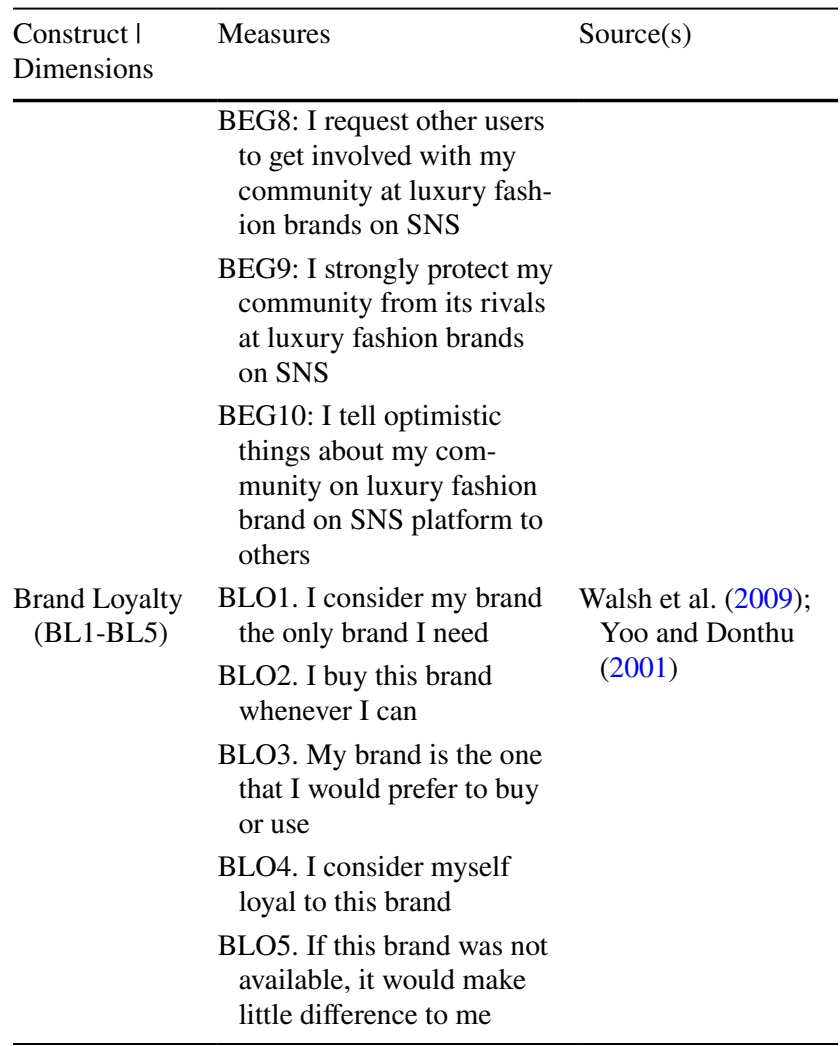

Acknowledgements The authors would like to extend their warm appreciation to the anonymous reviewers and Editor for their valuable comments to improve the quality of this work.

Author Contribution All authors contributed equally.

Funding Open Access funding provided by the Qatar National Library.

\section{Declarations}

Conflict of Interest The authors have no conflicts of interest to declare that are relevant to the content of this article.

Open Access This article is licensed under a Creative Commons Attribution 4.0 International License, which permits use, sharing, adaptation, distribution and reproduction in any medium or format, as long as you give appropriate credit to the original author(s) and the source, provide a link to the Creative Commons licence, and indicate if changes were made. The images or other third party material in this article are included in the article's Creative Commons licence, unless indicated otherwise in a credit line to the material. If material is not included in the article's Creative Commons licence and your intended use is not permitted by statutory regulation or exceeds the permitted use, you will need to obtain permission directly from the copyright holder. To view a copy of this licence, visit http://creativecommons.org/licenses/by/4.0/. 


\section{References}

Agichtein, E., Castillo, C., Donato, D., Gionis, A., \& Mishne, G. (2008). Finding high-quality content in social media. In Proceedings of the 2008 International Conference on Web Search and Data Mining, 183-194.

Ahuvia, A. C. (2005). Beyond the extended self: Loved objects and consumers' identity narratives. Journal of Consumer Research, 32(1), 171-184.

Alalwan, A. A., Algharabat, R. S., Baabdullah, A. M., Rana, N. P., Qasem, Z., \& Dwivedi, Y. K. (2020). Examining the impact of mobile interactivity on customer engagement in the context of mobile shopping. Journal of Enterprise Information Management, 33(3), 627-653.

Alalwan, A. A., Algharabat, R. S., Baabdullah, A. M., Rana, N. P., Raman, R., Dwivedi, R., \& Aljafari, A. (2019). Examining the impact of social commerce dimensions on customers' value cocreation: The mediating effect of social trust. Journal of Consumer Behaviour, 18(6), 431-446.

Alalwan, A. A., Rana, N. P., Algharabat, R., \& Tarhini, A. (2016). A systematic review of extant literature in social media in the marketing perspective. I3E Conference, Swansea University, UK (pp. 79-89). Springer, Cham.

Alalwan, A. A., Rana, N. P., Dwivedi, Y. K., \& Algharabat, R. (2017). Social Media in Marketing: A Review and Analysis of the Existing Literature. Telematics and Informatics, 34(7), 1177-1190.

Albert, N., Merunka, D., \& Valette-Florence, P. (2008). When consumers love their brands: Exploring the concept and its dimensions. Journal of Business Research, 61(10), 1062-1075.

Algharabat, R. (2017). Linking social media marketing activities with brand love: The mediating role of self-expressive brands. Kybernetes, 46(10), 1801-1819.

Algharabat, R., Rana, N. P., Alalwan, A. A., Baabdullah, A., \& Gupta, A. (2020). Investigating the antecedents of customer brand engagement and consumer-based brand equity in social media. Journal of Retailing and Consumer Services, 53, 101767.

Algharabat, R., Rana, N. P., Dwivedi, Y. K., Alalwan, A. A., \& Qasem, Z. (2018). The effect of telepresence, social presence and involvement on consumer brand engagement: An empirical study of non-profit organizations. Journal of Retailing and Consumer Services, 40, 139-149.

Algharabat, R. S. (2018). The role of telepresence and user engagement in co-creation value and purchase intention: Online retail context. Journal of Internet Commerce, 17(1), 1-25.

Algharabat, R. S., \& Rana, N. P. (2020). Social commerce in emerging markets and its impact on online community engagement. Information Systems Frontiers. https://doi.org/10.1007/ s10796-020-10041-4

Arenas-Gaitan, J., Rondan-Cataluna, F. J., \& Ramírez-Correa, P. E. (2013). Social identity, electronic word-of-mouth and referrals in social network services. Kybernetes, 42(8), 1149-1165.

Arrigo, E. (2018). Social media marketing in luxury brands: A systematic literature review and implications for management research. Management Research Review, 41(6), 657-679.

Ashley, C., \& Tuten, T. (2015). Creative strategies in social media marketing: An exploratory study of branded social content and consumer engagement. Psychology \& Marketing, 32(1), 15-27.

Aswani, R., Kar, A. K., \& Ilavarasan, P. V. (2018). Detection of spammers in twitter marketing: A hybrid approach using social media analytics and bio inspired computing. Information Systems Frontiers, 20(3), 515-530.

Barger, V., Peltier, J. W., \& Schultz, D. E. (2016). Social media and consumer engagement: A review and research agenda. Journal of Research in Interactive Marketing, 10(4), 268-287.

Batra, R., Ahuvia, A., \& Bagozzi, R. P. (2012). Brand love. Journal of Marketing, 76, 1-16.
Becker, J. M., Klein, K., \& Wetzels, M. (2012). Hierarchical latent variable models in PLS-SEM: Guidelines for using reflectiveformative type models. Long Range Planning, 45(5/6), 359-394.

Bento, M., Martinez, L. M., \& Martinez, L. F. (2018). Brand engagement and search for brands on social media: Comparing Generations $\mathrm{X}$ and $\mathrm{Y}$ in Portugal. Journal of Retailing and Consumer Services, 43, 234-241.

Brislin, R. W. (1976). Translation: Application and Research. Gardner Press Inc.

Brodie, R. J., Ilic, A., Juric, B., \& Hollebeek, L. (2013). Consumer engagement in a virtual brand community: An exploratory analysis. Journal of Business Research, 66(1), 105-114.

Bruhn, M., Schoenmueller, V., \& Schäfer, D. B. (2012). Are social media replacing traditional media in terms of brand equity creation? Management Research Review, 35(9), 770-790.

Calder, B. J., Malthouse, E. C., \& Schaedel, U. (2009). An experimental study of the relationship between online engagement and advertising effectiveness. Journal of Interactive Marketing, 23(4), 321-331.

Carroll, B. A., \& Ahuvia, A. C. (2006). Some antecedents and outcomes of brand love. Marketing Letters, 17(2), 79-89.

Chan, T. K., Zheng, X., Cheung, C. M., Lee, M. K., \& Lee, Z. W. (2014). Antecedents and consequences of customer engagement in online brand communities. Journal of Marketing Analytics, 2(2), 81-97.

Chatterjee, S., Rana, N. P., \& Dwivedi, Y. K. (2021). Assessing Consumers' Co-production and Future Participation On Value Co-creation and Business Benefit: An F-P-C-B Model Perspective. Information Systems Frontiers. https://doi.org/10.1007/ s10796-021-10104-0

Chen, N., Wang, Y., Li, J., Wei, Y., \& Yuan, Q. (2020). Examining structural relationships among night tourism experience, lovemarks, brand satisfaction, and brand loyalty on "cultural heritage night" in South Korea. Sustainability, 12(17), 6723.

Chen, Y., Fay, S., \& Wang, Q. (2011). The role of marketing in social media: How online consumer reviews evolve. Journal of Interactive Marketing, 25(2), 85-94.

Cheung, M. L., Pires, G. D., \& Rosenberger, P. J., III. (2019). Developing a conceptual Model for examining social media marketing effects on brand awareness and brand image. International Journal of Economics and Business Research, 17(3), 243-261.

Cheung, M. L., Pires, G. D., Rosenberger, P. J., III., \& De Oliveira, M. J. (2020a). Driving COBRAs: The power of social media marketing. Marketing Intelligence \& Planning. https://doi.org/ 10.1108/MIP-11-2019-0583

Cheung, M. L., Pires, G. D., Rosenberger, P. J., III., Leung, W. K., \& Ting, H. (2020b). Investigating the role of social media marketing on value co-creation and engagement: An empirical study in China and Hong Kong. Australasian Marketing Journal. https:// doi.org/10.1016/j.ausmj.2020.03.006

Cho, E., Fiore, A. M., \& Russell, D. W. (2015). Validation of a fashion brand image scale capturing cognitive, sensory, and affective associations: Testing its role in an extended brand equity model. Psychology \& Marketing, 32(1), 28-48.

Cho, E., Fiore, A. M., \& Yu, U. J. (2018). Impact of fashion innovativeness on consumer-based brand equity. Journal of Consumer Marketing, 35(3), 340-350.

Costello, A. B., \& Osborne, J. (2005). Best practices in exploratory factor analysis: Four recommendations for getting the most from your analysis. Practical Assessment, Research, and Evaluation, 10(7), 1-9.

Cross, S. E., Bacon, P. L., \& Morris, M. L. (2000). The relationalinterdependent self-construal and relationships. Journal of Personality and Social Psychology, 78(4), 791.

Cohen, J. (1988). Set correlation and contingency tables. Applied Psychological Measurement, 12(4), 425-434. 
Daugherty, T., Eastin, M. S., \& Bright, L. (2008). Exploring consumer motivations for creating user-generated content. Journal of Interactive Advertising, 8(2), 16-25.

De Vries, N. J., \& Carlson, J. (2014). Examining the drivers and brand performance implications of customer engagement with brands in the social media environment. Journal of Brand Management, 21(6), 495-515.

De Vries, L., Gensler, S., \& Leeflang, P. S. (2012). Popularity of brand posts on brand fan pages: An investigation of the effects of social media marketing. Journal of Interactive Marketing, 26(2), 83-91.

Dessart, L. (2017). Social media engagement: A model of antecedents and relational outcomes. Journal of Marketing Management, 33(5-6), 375-399.

Dessart, L., Veloutsou, C., \& Morgan-Thomas, A. (2015). Consumer engagement in online brand communities: A social media perspective. The Journal of Product and Brand Management, 24(1), 28-42.

Dessart, L., Veloutsou, C., \& Thomas, A. M. (2016). Capturing consumer engagement: Duality, dimensionality and measurement. Journal of Marketing Management, 32(5-6), 399-426.

Dhaoui, C. (2014). An empirical study of luxury brand marketing effectiveness and its impact on consumer engagement on Facebook. Journal of Global Fashion Marketing, 5(3), 209-222.

Dwivedi, A. (2015). A higher-order model of consumer brand engagement and its impact on loyalty intentions. Journal of Retailing and Consumer Services, 24, 100-109.

Dwivedi, Y. K., Ismagilova, E., Rana, N. P., \& Raman, R. (2021). Social media adoption, usage and impact in business-to-business (B2B) context: A state-of-the-art literature review. Information Systems Frontiers. https://doi.org/10.1007/s10796-021-10106-y

Fornell, C., \& Larcker, D. F. D. (1981). Evaluating structural equation models with unobservable variables and measurement error. Journal of Marketing Research, 18(1), 39-50.

Fournier, S. (1998). Consumers and their brands: Developing relationship theory in consumer research. Journal of Consumer Research, 24(4), 343-373.

France, C., Merrilees, B., \& Miller, D. (2016). An integrated model of customer-brand engagement: Drivers and consequences. Journal of Brand Management, 23(2), 119-136.

Frei, J. R., \& Shaver, P. R. (2002). Respect in close relationships: Prototype definition, self-report assessment, and initial correlates. Personal Relationships, 9(2), 121-139.

Gallaugher, J., \& Ransbotham, S. (2010). Social media and customer dialog management at Starbucks. MIS Quarterly Executive, 9(4), 197-212.

Gautam, V., \& Sharma, V. (2017). The mediating role of customer relationship on the social media marketing and purchase intention relationship with special reference to luxury fashion brands. Journal of Promotion Management, 23(6), 872-888.

Geissinger, A., \& Laurell, C. (2016). User engagement in social media: An explorative study of Swedish fashion brands. Journal of Fashion Marketing and Management: An International Journal, 20(2), 177-190.

Giertz, J. N., Weiger, W. H., Törhönen, M., \& Hamari, J. (2021). Content versus community focus in live streaming services: How to drive engagement in synchronous social media. Journal of Service Management, 33(1), 33-58.

Giovanis, A., \& Athanasopoulou, P. (2018). Understanding lovemark brands: Dimensions and effect on Brand loyalty in high-technology products. Spanish Journal of Marketing-ESIC, 22(3), 272-294.

Godey, B., Pederzoli, D., Aiello, G., Donvito, R., Wiedmann, K. P., \& Hennigs, N. (2013). A cross-cultural exploratory content analysis of the perception of luxury from six countries. Journal of Product \& Brand Management, 22(3), 229-237.

Godey, B., Manthiou, A., Pederzoli, D., Rokka, J., Aiello, G., Donvito, R., \& Singh, R. (2016). Social media marketing efforts of luxury brands: Influence on brand equity and consumer behavior. Journal of Business Research, 69(12), 5833-5841.

Habibi, M. R., Laroche, M., \& Richard, M. O. (2014). The roles of brand community and community engagement in building brand trust on social media. Computers in Human Behavior, 37, $152-161$.

Hair, J. F., Hult, G. T., Ringle, C. M., \& Sarstedt, M. (2014). A primer on partial least squares structural equation modeling (PLS-SEM) (1st ed.). SAGE Publications.

Hanna, R., Rohm, A., \& Crittenden, V. L. (2011). We're all connected: The power of the social media ecosystem. Business Horizons, 54(3), 265-273.

Hennig-Thurau, T., Wiertz, C., \& Feldhaus, F. (2015). Does Twitter matter? The impact of microblogging word of mouth on consumers' adoption of new movies. Journal of the Academy of Marketing Science, 43(3), 375-394.

Henseler, J., Ringle, C. M., \& Sinkovics, R. R. (2009). The use of partial least squares path modeling in international marketing. Advances in International Marketing, 20(3), 277-319.

Henseler, J., Ringle, C. M., \& Sarstedt, M. (2015). A new criterion for assessing discriminant validity in variance-based structural equation modeling. Journal of the Academy of Marketing Science, 43(1), 115-135.

Hidayanti, I., Herman, L. E., \& Farida, N. (2018). Engaging customers through social media to improve industrial product development: The role of customer co-creation value. Journal of Relationship Marketing, 17(1), 17-28.

Holland, S. J., Shore, D. B., \& Cortina, J. M. (2017). Review and recommendations for integrating mediation and moderation. Organizational Research Methods, 20(4), 686-720.

Hollebeek, L. D. (2011a). Demystifying customer brand engagement: Exploring the loyalty nexus. Journal of Marketing Management, 27(7-8), 785-807.

Hollebeek, L. D. (2011b). Exploring customer brand engagement: Definition and themes. Journal of Strategic Marketing, 19(7), 555-573.

Hollebeek, L. D., Conduit, J., \& Brodie, R. J. (2016). Strategic drivers anticipated and unanticipated outcomes of customer engagement. Journal of Marketing Management, 32(5-6), 393-398.

Hollebeek, L. D., Glynn, M., \& Brodie, R. (2014). Consumer brand engagement in social media: Conceptualization, scale development and validation. Journal of Interactive Marketing, 28(2), 149-165.

Hoyer, W. D., Chandy, R., Dorotic, M., Krafft, M., \& Singh, S. S. (2010). Consumer cocreation in new product development. Journal of Service Research, 13(3), 283-296.

Huber, F., Meyer, F., \& Schmid, D. A. (2015). Brand love in progressthe interdependence of brand love antecedents in consideration of relationship duration. Journal of Product \& Brand Management, 24(6), 567-579.

Hutter, K., Hautz, J., Dennhardt, S., \& Füller, J. (2013). The impact of user interactions in social media on brand awareness and purchase intention: The case of MINI on Facebook. Journal of Product \& Brand Management., 22(2), 342-351.

Ibrahim, B. (2021). Social Media Marketing Activities and Brand Loyalty: A Meta-Analysis Examination. Journal of Promotion Management, 1-31.

Islam, J. U., \& Rahman, Z. (2016). Linking customer engagement to trust and word-of-mouth on Facebook brand communities: An empirical study. Journal of Internet Commerce, 15(1), 40-58

Ismail, A. R. (2017). The influence of perceived social media marketing activities on brand loyalty: The mediation effect of brand and value consciousness. Asia Pacific Journal of Marketing and Logistics, 29(1), 129-144.

Kapferer, J. N. (2012). New strategic brand management: Advanced insights and strategic thinking, 5th ed., GBR: Kogan Page Ltd, London. 
Kaplan, A. M., \& Haenlein, M. (2010). Users of the world, unite! The challenges and opportunities of social media. Business Horizons, 53(1), 59-68.

Kapoor, K. K., Tamilmani, K., Rana, N. P., Patil, P., Dwivedi, Y. K., \& Nerur, S. (2018). Advances in social media research: Past, present and future. Information Systems Frontiers, 20(3), 531-558.

Kar, A. K. (2021). What affects usage satisfaction in mobile payments? Modelling user generated content to develop the "digital service usage satisfaction model." Information Systems Frontiers, 23(5), $1341-1361$.

Keller, K. L. (1993). Conceptualizing, measuring, and managing customer-based brand equity. Journal of Marketing, 57(1), 1-22.

Kelly, L., Kerr, G., \& Drennan, J. (2010). Avoidance of advertising in social networking sites: The teenage perspective. Journal of Interactive Advertising, 10(2), 16-27.

Khan, Z., Yang, Y., Shafi, M., \& Yang, R. (2019). Role of social media marketing activities (SMMAs) in apparel brands customer response: A moderated mediation analysis. Sustainability, 11(19), 5167.

Kim, A. J., \& Ko, E. (2010). Impacts of luxury fashion brand's social media marketing on customer relationship and purchase intention. Journal of Global Fashion Marketing, 1(3), 164-171.

Kim, A. J., \& Ko, E. (2012). Do social media marketing activities enhance customer equity? An empirical study of luxury fashion brand. Journal of Business Research, 65(10), 1480-1486.

Koivisto, E., \& Mattila, P. (2018). Extending the luxury experience to social media-User-Generated Content co-creation in a branded event. Journal of Business Research, 117, 570-578.

Kudeshia, C., \& Kumar, A. (2017). Social eWOM: does it affect the brand attitude and purchase intention of brands? Management Research Review, 4(3), 310-330.

Laroche, M., Habibi, M. R., \& Richard, M. O. (2013). To be or not to be in social media: How brand loyalty is affected by social media?. International Journal of Information Management, 33(1), 76-82.

Leckie, C., Nyadzayo, M., \& Johnson, L. (2016). Antecedents of consumer brand engagement and brand loyalty. Journal of Marketing Management, 32(5-6), 558-578.

Liu, F., Li, J., Mizerski, D., \& Soh, H. (2012). Self-congruity, brand attitude, and brand loyalty: A study on luxury brands. European Journal of Marketing, 46(7/8), 922-937.

Liu, S., Perry, P., \& Gadzinski, G. (2019). The implications of digital marketing on WeChat for luxury fashion brands in China. Journal of Brand Management, 26(4), 395-409.

Liu, X., Shin, H., \& Burns, A. C. (2021). Examining the impact of luxury brand's social media marketing on customer engagement: Using big data analytics and natural language processing. Journal of Business Research, 125, 815-826.

Lusch, R. F., \& Vargo, S. L. (2010). S-D logic: Accommodating, integrating. Grand Service Challenge, University of Cambridge.

Mackenzie, S. B., Podsakoff, P. M., \& Podsakoff, N. P. (2011). Construct measurement and validation procedures in MIS and behavioral research: Integrating new and existing techniques. MIS Quarterly, 35(2), 293-334.

Mangold, W. G., \& Faulds, D. J. (2009). Social media: The new hybrid element of the promotion mix. Business Horizons, 52(4), 357-365.

Manthiou, A., Chiang, L., \& Tang, L. R. (2013). Identifying and responding to customer needs on Facebook fan pages. International Journal of Technology and Human Interaction, 9(3), 36-52.

Manthiou, A., Tang, L. R., \& Bosselman, R. (2014). Reason and reaction: The dual route of the decision-making process on Facebook fan pages. Electronic Markets, 24(4), 297-308.

Merrilees, B. (2016). Interactive brand experience pathways to customer-brand engagement and value co-creation. Journal of Product \& Brand Management, 25(5), 402-408.
Mirkovski, K., Yin, C., Liu, L., \& Yang, J. (2019). Exploring the contingent effect of community equity on users' intention to share information. Information Systems Frontiers, 21(4), 845-860.

Mishra, A., Dash, S. B., \& Cyr, D. (2014). Linking user experience and consumer-based brand equity: The moderating role of consumer expertise and lifestyle. Journal of Product \& Brand Management, 23(4/5), 333-348.

Muntinga, D. G., Moorman, M., \& Smit, E. G. (2011). Introducing COBRAs: Exploring motivations for brand-related social media use. International Journal of Advertising, 30(1), 13-46.

Naaman, M., Becker, H., \& Gravano, L. (2011). Hip and trendy: Characterizing emerging trends on Twitter. Journal of the American Society for Information Science and Technology, 62(5), 902-918.

Najjar, M. S., Dahabiyeh, L., \& Algharabat, R. S. (2021). Users' affect and satisfaction in a privacy calculus context. Online Information Review. https://doi.org/10.1108/OIR-02-2019-0054

Nam, K., Baker, J., Ahmad, N., \& Goo, J. (2020). Dissatisfaction, disconfirmation, and distrust: An empirical examination of value codestruction through negative electronic word-of-mouth (eWOM). Information Systems Frontiers, 22, 113-130.

Nyadzayo, M. W., Johnson, L. W., \& Rossi, M. (2020). Drivers and outcomes of brand engagement in self-concept for luxury fashion brands. Journal of Fashion Marketing and Management: An International Journal, 24(4), 589-609.

Obeidat, Z. M., AlGharabat, R. S., Alalwan, A. A., Xiao, S. H., Dwivedi, Y. K., \& Rana, N. P. (2020). Narcissism, interactivity, community, and online revenge behavior: The moderating role of social presence among Jordanian consumers. Computers in Human Behavior, 104, 106170.

Okazaki, S. (2009). The tactical use of mobile marketing: How adolescents' social networking can best shape brand extensions. Journal of Advertising Research, 49(1), 12-26.

Park, N., Kee, K. F., \& Valenzuela, S. (2009). Being immersed in social networking environment: Facebook groups, uses and gratifications, and social outcomes. Cyberpsychology \& Behavior, 12(6), 729-733.

Pawle, J., \& Cooper, P. (2006). Measuring emotion-Lovemarks, the future beyond brands. Journal of Advertising Research, 46(1), $38-48$.

Pentina, I., Guilloux, V., \& Micu, A. C. (2018). Exploring social media engagement behaviors in the context of luxury brands. Journal of Advertising, 47(1), 55-69.

Phan, M., Thomas, R., \& Heine, K. (2011). Social media and luxury brand management: The case of Burberry. Journal of Global Fashion Marketing, 2(4), 213-222.

Plume, C. J., \& Slade, E. L. (2018). Sharing of sponsored advertisements on social media: A uses and gratifications perspective. Information Systems Frontiers, 20, 471-483.

Podsakoff, P. M., MacKenzie, S. B., Lee, J. Y., \& Podsakoff, N. P. (2003). Common method biases in behavioral research: A critical review of the literature and recommended remedies. Journal of Applied Psychology, 88(5), 879-903.

Preuveneers, D., Garofalo, G., \& Joosen, W. (2020). Cloud and edge based data analytics for privacy-preserving multi-modal engagement monitoring in the classroom. Information Systems Frontiers, 1-14.

Rana, N. P., \& Dwivedi, Y. K. (2016). Using clickers in a large business class: Examining use behavior and satisfaction. Journal of Marketing Education, 38(1), 47-64.

Ringle, C. M., Sarstedt, M., \& Straub, D. W. (2012). Editor's comments: A critical look at the use of PLS-SEM in "MIS Quarterly." MIS Quarterly, 36(1), iii-xiv.

Ringle, C. M., Wende, S., \& Becker, J. -M. (2015). SmartPLS 3, available at: https://www.smartpls.com. Accessed 20 May 2021.

Roberts, K. (2005). Lovemarks: The future beyond brands (2nd ed.). Powerhouse Books. 
Rohm, A., Kaltcheva, V. D., \& Milne, G. R. (2013). A mixed-method approach to examining brand-consumer interactions driven by social media. Journal of Research in Interactive Marketing, 7(4), 295-311

Rossiter, J. R., \& Percy, L. (1987). Advertising and promotion management. McGraw-Hill Book Company.

Sijoria, C., Mukherjee, S., \& Datta, B. (2018). Impact of the antecedents of eWOM on CBBE. Marketing Intelligence \& Planning, $36(5), 528-542$.

Schivinski, B., \& Dabrowski, D. (2015). The impact of brand communication on brand equity through Facebook. Journal of Research in Interactive Marketing, 9(1), 31-53.

Schmenner, R. W. (1986). How can service businesses survive and prosper. Sloan Management Review, 27(3), 21-32.

Schultz, D. E., \& Peltier, J. J. (2013). Social media's slippery slope: Challenges, opportunities and future research directions. Journal of Research in Interactive Marketing, 7(2), 86-99.

Shareef, M. A., Mukerji, B., Dwivedi, Y. K., Rana, N. P., \& Islam, R. (2019). Social media marketing: Comparative effect of advertisement sources. Journal of Retailing and Consumer Services, 46, 58-69.

Seo, E. J., \& Park, J. W. (2018). A study on the effects of social media marketing activities on brand equity and customer response in the airline industry. Journal of Air Transport Management, 66, 36-41.

Sharma, S. (1996). Applied multivariate techniques. John Wiley \& Sons.

Shimp, T. A., \& Madden, T. J. (1988). Consumer-object relations: A conceptual framework based analogously on Sternberg's triangular theory of love. In NA - Advances in Consumer Research Volume 15, eds. Micheal J. Houston, Provo, UT: Association for Consumer Research, 163-168.

Simon, F., \& Tossan, V. (2018). Does brand-consumer social sharing matter? A relational framework of customer engagement to brand-hosted social media. Journal of Business Research, 85, $175-184$.

Sternberg, R. J. (1986). A triangular theory of love. Psychological Review, 93(2), 119-135.

Sternberg, R. J. (1997). Construct validation of a triangular love scale. European Journal of Social Psychology, 27(3), 313-335.

Swani, K., Milne, G., \& Brown, B. P. (2013). Spreading the word through likes on Facebook. Journal of Research in Interactive Marketing, 7(4), 269-294.

Tamilmani, K., Rana, N. P., \& Dwivedi, Y. K. (2021). Consumer acceptance and use of information technology: A meta-analytic evaluation of UTAUT2. Information Systems Frontiers, 23(4), 987-1005.

Thomson, M., MacInnis, D. J., \& Whan Park, C. (2005). The ties that bind: Measuring the strength of consumers' emotional attachments to brands. Journal of Consumer Psychology, 15(1), 77-91.

Trivedi, N., Asamoah, D. A., \& Doran, D. (2018). Keep the conversations going: Engagement-based customer segmentation on online social service platforms. Information Systems Frontiers, 20(2), 239-257.

Tsai, W. H. S., \& Men, L. R. (2017). Consumer engagement with brands on social network sites: A cross-cultural comparison of
China and the USA. Journal of Marketing Communications, 23(1), 2-21.

Vargo, S., \& Lusch, R. F. (2008). Service-dominant logic: Continuing the evolution. Journal of the Academy of Marketing Science, 36(1), 1-10.

Veloutsou, C., \& Aimpitaksa, J. B. (2017). The lovemarks effect: an abstract, in Krey N., Rossi P. (Eds.), AMSAC 2017. Developments in Marketing Science: Proceedings of the Academy of Marketing Science, Springer, Cham, 259-260, available at: https://doi.org/10.1007/978-3-31966023-3, https://link.sprin ger.com/chapter/10.1007/978-3-319-66023-3_94. Accessed 5 May 2021.

Vernuccio, M., Pagani, M., Barbarossa, C., \& Pastore, A. (2015). Antecedents of brand love in online network-based communities: A social identity perspective. Journal of Product \& Brand Management., 24(7), 706-719.

Vivek, S. D., Beatty, S. E., \& Morgan, R. M. (2012). Customer engagement: Exploring customer relationships beyond purchase. Journal of Marketing Theory and Practice, 20(2), 122-146.

Wallace, E., Buil, I., \& de Chernatony, L. (2014). Consumer engagement with self-expressive brands: Brand love and WOM outcomes. Journal of Product \& Brand Management, 23(1), 33-42.

Wallace, E., Buil, I., \& de Chernatony, L. (2017). Consumers' selfcongruence with a "Liked" brand. European Journal of Marketing, 51(2), 367-390.

Walsh, G., Beatty, S. E., \& Shiu, E. M. (2009). The customer-based corporate reputation scale: Replication and short form. Journal of Business Research, 62(10), 924-930.

Wirtz, J., Den Ambtman, A., Bloemer, J., Horváth, C., Ramaseshan, B., Van De Klundert, J., ... \& Kandampully, J. (2013). Managing brands and customer engagement in online brand communities. Journal of Service Management, 24(3), 223-244.

Yazdanparast, A., Joseph, M., \& Muniz, F. (2016). Consumer based brand equity in the 21st century: An examination of the role of social media marketing. Young Consumers, 17(3), 243-255.

Yoo, B., \& Donthu, N. (2001). Developing and validating a multidimensional consumer-based brand equity scale. Journal of Business Research, 52(1), 1-14.

Zacchilli, T. L., Hendrick, C., \& Hendrick, S. S. (2009). The romantic partner conflict scale: A new scale to measure relationship conflict. Journal of Social and Personal Relationships, 26(8), 1073-1096.

Zaglia, M. E. (2013). Brand communities embedded in social networks. Journal of Business Research, 66(2), 216-223.

Zhang, L., Zhao, H., \& Cude, B. (2021). Luxury brands join hands: Building interactive alliances on social media. Journal of Research in Interactive Marketing, 15(4), 787-803.

Zhu, Y. Q., \& Chen, H. G. (2015). Social media and human need satisfaction: Implications for social media marketing. Business Horizons, 58(3), 335-345.

Ziggers, G. W., \& Henseler, J. (2016). The reinforcing effect of a firm's customer orientation and supply-base orientation on performance. Industrial Marketing Management, 52, 18-26.

Publisher's Note Springer Nature remains neutral with regard to jurisdictional claims in published maps and institutional affiliations. 
Abdulla H. Fetais is an Assistant Professor and the Head of the Department of Management and Marketing at Qatar University, Doha, Qatar. $\mathrm{He}$ received his $\mathrm{PhD}$ in Project Management from University of Northumbria, UK in 2015, and holds an MBA from University of Sheffield, UK. He completed his bachelor's degree in management from Qatar University, Qatar. He joined Qatar University in 2016. He has also qualified the Qatar Leadership Centre's Executive Leadership Program in 2019. His research interests include project management and strategic planning. He has published his work in some well-known international refereed journals and presented at some international conferences in his area of research.

Raed S. Algharabat is a Professor in digital marketing and social media at the College of Business and Economics (CBE), Department of Management and Marketing, Qatar University, Doha, Qatar. Prof. Algharabat research area includes digital marketing; (e)retail and consumer behaviour, particularly, 3D virtual models and their impact on consumer behaviour within the online retailer context. Furthermore, Prof. Algharabat research area focused on social media, particularly, customer brand engagement, online community engagement and cocreation. Prof. Algharabat publications appeared in reputed marketing, IS and IT journals such as Computers in Human Behavior, Information Systems Frontiers, Telematics and Informatics, Journal of Retailing and Consumer Services, Journal of Enterprise Information Management, Journal of Internet Commerce, Journal of Consumer Behaviour and Kybernetes. Prof. Algharabat received the best paper awards for papers related to e-marketing and social media conferences. Prof. Algharabat has published one book on Principles of Marketing and has translated another book in B2B.
Abdullah Aljafari is an Assistant Professor of Marketing in the Department of Management and Marketing at Qatar University, Doha, Qatar. His research work has appeared in Journal of Consumer Behaviour, Journal of Business \& Industrial Marketing, Journal of Global Marketing, American Marketing Association (AMA), Academy of Marketing Science (AMS), and the Association of Collegiate Marketing Educators (ACME) conference proceedings.

Nripendra P. Rana is a Professor in Marketing at the College of Business and Economics at Qatar University, Doha, Qatar. His current research interests focus primarily on adoption and diffusion of emerging ICTs, e-commerce, m-commerce, e-government and digital and social media marketing. He has published more than 250 papers in a range of leading academic journals, conference proceedings, books etc. He has co-edited five books on digital and social media marketing, emerging markets and supply and operations management. He has also co-edited special issues, organised tracks, mini-tracks and panels in leading conferences. He is a Chief Editor of International Journal of Electronic Government Research and an Associate Editor of International Journal of Information Management. He is also a Senior Fellow of the Higher Education Academy (SFHEA) in the UK. 